Tarih Kültür ve Sanat Araştırmaları Dergisi

Revue des Recherches en Histoire Culture et Art مجلة البحوث التاريخية و الثقافية والفنية
Vol. 7, No. 5, December 2018

Copyright (C) Karabuk University

http://kutaksam.karabuk.edu.tr

\title{
DOI: 10.7596/taksad.v7i5.1517
}

Citation: Tezcan, T. (2018). Hayruddin Hızır el-Atûfî ve Keşşâf Haşiyesi. Journal of History Culture and Art Research, 7(5), 782-802. doi:http://dx.doi.org/10.7596/taksad.v7i5.1517

\section{Hayruddin Hızır el-Atûfî ve Keşşâf Haşiyesi*}

\section{Khair al-Din Khidir al-Atufi and His Hashiya on al-Kashshaf}

Tuğrul Tezcan ${ }^{1}$

\begin{abstract}
Al-Atufi, a scholar born in Merzifon witnessed the eras of Bayazid II, Selim I and Suleiman I and was employed as a tutor in the palace in the period of Bayazid II. He had long engaged in preaching through tafsir lessons in various mosques in İstanbul before he died there in 1541.

He wrote commentaries in miscellaneous fields, such as tafsir, hadith, al-tibb al-nabawi, ta'bir al-ru'ya and logic. He authored three commentaries and a treatise interpreting a verse, namely Hashiya ala al-Kashshaf - from al-Naba' to al-Nas, Hashiya ala Anwar al-Tanzil, and on al-Baidawi's interpretation of a verse in alMulk: Risala fi Bayan Tafsir Qawlih Ta'ala 'Fa-suhqan' and Hisn al-Ayat al-Izam fi Tafsir Awail Sura al-An'am.

Employing maani and bayan in his commentaries, al-Atufi successfully transformed the knowledge to gnosis. He displays the subtleties of the way from the cause to the effect regarding lugha, nahw and balagha. Similar characteristics of al-Atufi can be seen in his Hashiya ala al-Kashshaf. The comments made on what al-Zamakhshari touched briefly are occasionally meant to criticize. Al-Atufi quoted directly from alNasafi, al-Baidawi and so forth in tafsir, from al-Farra, al-Sakkaki and Ibn Juraij in lugha and from Ibn Abbas, Muqatil and others in riwaya. He levelled criticisms at some whose views quoted, within the scope of lugha. He referred to al-Zamakhshari as müsannif recounting his opinions with 'qawluhu'. He used alZamakhshari's way of interpretation: 'said - I say'. Ignoring his views on the issues of faith, he expressed his own opinions writing a supplement.
\end{abstract}

There he examined the most recited chapters in prayers and elucidated the parts to be misunderstood calling them 'the slippery spots'.

Al-Atufi dedicated his Hashiya on al-Kashshaf to Suleiman.

Keywords: The Ottoman mufassir, Atufi, Merzifonian, Hashiya, Hashiya on al-Kashshaf.

\footnotetext{
* Bu makale “OSMANLI DÖNEMI TÜRK TEFSIR EKOLÜ” (27-28 Ekim 2017) Sempozyumunda HAYRUDDIN HIZIR ELATÛFÎ VE KEŞŞÂF HAŞIYESI ismiyle sunulmuş ve yayımlanmamış bildirinin geliştirilmesiyle oluşmuştur. ${ }^{1}$ Dr. Öğr. Üyesi, Karabük Üniversitesi, İlahiyat Fakültesi, Karabük, Türkiye. E-mail: tutez73@gmail.com
} 
Atûfî, Bayezid, Selim ve Süleyman Han devirlerine şâhid olmuş, özellikle Bayezid döneminde sarayda muallimlik yapmış, hayatının önemli bir bölümünde i̇stanbul camilerinde Cumâ günleri tefsir dersleri yaparak irşâd faaliyetinde bulunmuş ve $948 / 1541$ 'te yine i̇stanbul'da vefat etmiş, Merzifon doğumlu önemli bir âlimdir.

Tefsir'den Hadis'e, Tıbbu'n-Nebevî'den rüyâ tâbiri ve mantık ilmine kadar birçok alanda şerhi bulunan Atûfî'nin tefsîre dair üç şerhi, bir de müstakil ayet tefsiri vardır. Bunlar, "Hâşiye ale'I-Keşşâf" (Nebe'den Nâs'a), "Hâşiyetün ala Envâri't-Tenzîl li'l-Beydâvî", Beydâvî'nin bir ayet tefsirini şerheden "Risale fi Beyâni Tefsîr-i Kavlihî Teâlâ - Fe-Suhkan" ve müstakil bir ayet tefsiri olan “Hısnü'I-Âyati'l-Izâm fî Tefsiri Evâili Sûreti'IEn'âm" isimli eserdir.

Özellikle meânî ve beyân ilmini şerhlerinde etkin bir şekilde yansıtan Atûfî, Sebeb'ten müsebbibe giden yolun lugavî, nahvî ve belâgatla ilgili inceliklerini şerhlerinde sergilemiştir. Bu makalenin inceleme konusunu olan Keşşâf hâşiyesinde de benzer özellikleri ziyâdesiyle görülmüştür. Zemahşerî’nin yeterince açıklamadığı kelime ve cümlelere yoğunlaşan şerhleri, bazen eleştiri dilini de kullanmıştır. Tefsirde Nesefî ve Beydâvî gibi meşhur müfessirlerin görüşlerinden, lügavî alanda Ferra, Sekkâkî, ỉbn Cüreyc'den, rivayet konusunda da çoğunlukla İbn Abbas, Mukâtil'den istifade etmiştir. Zemahşerî́nin başka alimlerden naklettiği bazı görüşleri de dilbilimi kapsamında eleştirmiştir. Zemahşerî’yi haşiye süresince müsannif olarak ifade eden, görüşlerini "kavlühü" diyerek nakleden müfessir, Zemahşerî̀nin üslûbundan esinlenerek "fenkale" tarzını da şerhinde kullanmıştır. Zemahşerî'nin itikâdî görüşlerine imkan nisbetinde girmeyen Atûfî, açıklama gereği hissettiği konuları bir "tetimme" başlı̆ı altında kaleme almıştır. Nebe ile Nas arasındaki sûrelerin tefsirinin şerhi esnasında "Mezâliku'I-Mahal” dediği yanlış anlaşılabilecek kısımlara ağırlık vermiştir.

Şiiri seven, şiirden istişhatta bulunan müellif, Keşşâf hâşiyesini Sultan Süleyman’a ithaf etmiştir.

Anahtar kelimeler: Osmanlı müfessiri, Atûfî, Merzifon'lu, Hâşiye, Keşşâf Hâşiyesi.

\section{Giriş}

Doğum tarihi hakkında bilgi bulunmayan ancak vefatı 948/1541 senesinde ${ }^{2}$ istanbul'da gerçekleşen Hayruddin Hızır el-Atûfî, Sultan Bayezid, Sultan Selim ve Sultan Süleyman dönemlerinde yaşamıştır. II. Bayezid döneminde saray muallimliği, ìstanbul'un salâtin câmîlerinde vaizlik görevlerinde bulunmuştur. ${ }^{3}$

Dönemin eğitim kültür hayatına ışık tutan çalışmalara imza atan İsmail E. Erünsal, Fatih Sultan Mehmed'in ilgi Duyduğu Kitaplar ve Kütüphanesi başlıklı bildirisinde, tabakât kitaplarında rastlanmayan şöyle bir tespite yer verir: Fatih döneminde oluşturulan kütüphaneye II. Bayezid devrinde (908/1502) 5700 cilt içinde 7200 eserin künyesinin bulunduğu 340 yapraktan oluşan katolog hazırlanmış, kataloğu hazırlayanın ise kütüphanenin hafız-ı kütüb'ü Atûfî olduğu ifade edilmiştir. ${ }^{4}$ Yani Atûfî, vâiz, muallim ve hâfız-ı kütüb'dür.

Atûfî eğitimini çoğunlukla Amasya âlimlerinden alması sebebiyle gençliğinin Amasya'da geçtiği düşünülebilir. Zira dönemin âlimlerinden Bahşî Efendi'den Tefsir ve Hadis ilmini, Amasya'lı Abdî'den İlm-i Maâni'yi, Kadızâde torunu Kutbuddin Muhammed'den aklî ilimleri ve Bursalı Mevlânâ Hocazâde'den usul ilmini ve Efdalzâde'den şer'î ilimleri öğrenmiş, zamanının parmakla gösterilen alimleri arasına girmiştir. Merzifon'lu bir araştırmacı olan Seyfettin Ceylanın verdiği bilgilere göre Atûfî Gelgiraslı'dır. Gelgiras Merzifon'un bir köyüdür. Yine Merzifon sınırları içinde yer alan Yakup, Hayrettin ve Illemi köyleri isimlerini

\footnotetext{
${ }^{2}$ Aḥmed b. Mușțafā b. Halîl, Taşköprîzâde, eş-Şekâiku'n-Nu'mâniyye fí Ulemâi'd-Devleti'l-is/âmiyyeti s.249-250.

${ }^{3}$ Taşköprîzâde, eş-Şekâiku'n-Nu'mâniyye, s.249-250.

${ }^{4}$ İsmâil E. Erünsal, Osmanlılarda Kütüphaneler ve Kütüphanecilik, s. 116.
} 
Atûfî'nin çocuklarının isimlerinden [büyükten küçüğe doğru kardeşlerinin isimleri Hayrettin, Yakup, IIEmin'dir] almıştır. Çünkü bu köyler II. Bayezid döneminde Atufî́nin Babasına çiftlik olarak verilmiş sonra Âtufî'nin çocukları arasında miras sebebiyle bölüşülüp kendi isimleriyle müsemmâ köyler oluşmuştur. ${ }^{5}$ Necâtü'l-Akabât isimli risâlede Atûfî'nin "Merzifonî" nisbesini kullanması, ${ }^{6}$ tabakat kitaplarından bazısının onun Merzifonlu olduğundan bahsetmesi ${ }^{7}$ Amasya ili Merzifon ilçesinde yaşadığını teyid etmektedir.

Ayrıca Atufînin belli bir dönem Kastamonu'da bulunmuş olmasından mülhem eş-Şekâiku'n-Nu'mâniyye ve Sicill-i Osmânî'de müelliften 'Kastamonî' nisbesiyle de bahsedildiği unutulmamalıdır.

Atûfî'nin yaptığı çalışmalar kaynaklarda farklı zikredilmiştir. Herhangi bir kaynakta çalışmalarını tam olarak bulma şansına sahip değiliz. Osmanlı dönemi âlimleri hakkında bilgi veren en yetkin tabakât kitabı olan eşşekâiku'n-Nu'mâniyye genel bir ifade ile onun eserlerini dört alana hasretmiş ve detaya girmemiştir. Büyük oranda eş-Şekâiku'n-Nu'mâniyye'den iktibaslar yapılarak hazırlanmış ikinci önemli kaynak olan Keşfü'zZunûn'da ise hayatı hakkında detaylı bilgi bulunmazken on adet eserinden ve bu eserlerinin bazılarının muhtevalarından bahsedilmektedir. Mesela, "şerh" diye bir çalışmadan bahseder ${ }^{8}$ ancak bu şerhin mahiyetinden bahsetmez. Halbûkî, Atûfî́nin çalışmalarının çoğunluğu şerh ve hâşiye tarzındadır. Bu minval üzere Kasîde-i Bürde'den sadece "onu şerhetti" ${ }^{9}$ diye bahseder. Tefsir tarzı çalışmalarının en önemlisi sayılan Keşşâf Hâşiyesi'ne değinmeksizin, "Keşşâf üzerine çalışma yapanlar arasındadır" 10 ifadesi ile müellife atıfta bulunmuştur. Bazı eserlerinden ise kısaca bahsetmiştir. Meselâ Sultan Bâyezid için hazırlananlardan Hıfzu'l-Ebdân hakkında "bu eser kasîde-i lâmiyye tarzındadır. Evveli el-hamdü li'llâh min a'le'l-makâl..." ifadesiyle başlar ${ }^{11}$ demiştir. Zehru'I-Atşân'ın "Tıp'la ilgili manzum bir eser" ${ }^{12}$; Ramzü'd-Dekâik'in "Rüya ta'biri, manzum, Türkçe, iki varak, tanzim tarihinin 904/1498 olduğu" 13; Ravzu'I-insan fî Terbiyeti Sıhhati'lEbdân isimli eserin de yine "Tıbbı'n-Nebevî ile ilgili ve evvelinin el-Hamdü li'llâhi'l-Kâfî ve's-Salâtü alâ Nebiyyi'ş-Şâfî...ile başladığına” değinmiştir.. ${ }^{14}$

Hacı Halife'nin ve el-Ednevî'nin kısaca bahsettiği ${ }^{15}$ diğer eserlerden birisi, Keşfü'l-Meşârık'tır. Bu eser, Sâgânî'nin Meşâriku'I-Envâri'n-Nebeviyye'sinin şerhidir ve üç cilttir. ${ }^{16}$ Diğeri, eş-Şemsiyye isimli, Nasıruddin Tûsînnin talebesi Ömer b. Ali el-Kazvînîye (ö.693/1293) ait olan eserdir. Atûfî tarafından Sultan Süleyman Han için 930/1523 senesinde tasnifi tamamlanmıştır. ${ }^{17}$ Bir diğer eser de Remzu'd-Dekâik'dan başka rüya tabiri için yazdığı Mirâtü'r-Rü'ya'dır. ${ }^{18}$ Atufî ve eserlerinden bahseden fakat verdiği bilgiler itibariyle kuşatıcı olmayan Zirikli'nin A'lâm' ${ }^{19}$, Osmanlı alimleri ve eserleri hakkında bilgi veren Keşfü'z-Zünün ve eş-Şekâiku'nNu'mâniyye'den başka yakın tarihli tabakat kitaplarının bazılarında Atûfínin eserleri tam liste halinde sunulmuştur. Meselâ, Hediyyetü'l-Ârifîn'de on beş adet eserin ismi zikredilir. Bu eserler arasında eşŞekâiku'n-Nu'mâniyye ve Keşfü'z-Zünûn'un zikretmediği, Hâş̧iyetün ala Envâri't-Tenzîl li Beydâvî, Hısnü'lÂyati'l-Izâm fî Tefsir-i Evâil-i Sûreti'I-En'âm, el-Cevherâtü'I-Cinâiyye fi Mesâili'l-Imaniyye, Risâletün fi'l-

\footnotetext{
${ }^{5}$ https://ipfs.io/ipns/tr.wikipedia-on-ipfs.org/wiki/Sazl\%C4\%B1ca\%2C_Merzifon.html

${ }^{6}$ Bkz. Atûfî, Hâşiyetü 'ale'l-Keşşâf li'l-'Atûfí, Süleymaniye Ktp., Yeni Camii, nr. 144, vr. 194' ${ }^{\mathrm{b}}-202^{\mathrm{b}}$

${ }^{7}$ Hayruddin ez-Ziriklî, el-A'lâm Kâmûsu Terâcimi'l-Eşheri'r-Ricâl ve'n-Nisâ' mine'l-'Arab ve'l-Musta'rabîn ve'lMusteşriḳin, II, s.307; Adil Nüveyhiz, Mu'cemü'l-Müfessirîn, s. 378-79.

8 Kâtip Çelebî (Hacı Halife), Keşfü'z-Zünûn, I, s.208.

9 Kâtip Çelebî, Keşfü'z-Zünûn, II, s.1331.

10 Kâtip Çelebî, Keşfü'z-Zünûn, II, s.1475.

${ }^{11}$ Kâtip Çelebî, Keşfü'z-Zünûn, II, s.671.

12 Kâtip Çelebî, Keşfü'z-Zünûn, I, s. 822.

${ }^{13}$ Kâtip Çelebî, Keşfü'z-Zünûn, I, s.912.

${ }^{14}$ Kâtip Çelebî, Keşfü'z-Zünûn, I, s.917.

${ }^{15}$ El- Ednevî, Tabakâtül- Müfessirîn, 1.bsk., tahk. Süleyman b. Salih el-Huzey, I, s. 378-79.

${ }^{16}$ Kâtip Çelebî, Keşfü'z-Zünûn, II, s.1689.

${ }^{17}$ Kâtip Çelebî, Keşfü'z-Zünûn, II, s.1063.

18 Kâtip Çelebî, Keşfü'z-Zünûn, II, s.1647.

${ }^{19}$ Ez-Ziriklî ed-Dımeşkî, el-A'lâm, 15.bsk. II, s.307.
} 
Kelâm, Şerhu Îsâgûcî vardır. ${ }^{20}$ Kehhâle'nin (ö.1905) Mu'cemü'l-Müellifîn'i, ${ }^{21}$ de bu eserlere yer verenler arasındadır. "Fesuhkan li Ashabi's-Seîr" adlı risale ise hiçbir kaynakta yer almamakta ancak risâle Süleymaniye Kütüphanesi'nde üç nüsha halinde bulunmaktadır. ${ }^{22}$ Ayrıca yazmalar.gov.tr adresinde, $28 \mathrm{Hk}$ 3572/1 koduyla, Giresun Halk Kütüphanesinde bulunan yazma eserin zâhirî yapısıyla alâkalı olarak bilgi verilmektedir. ${ }^{23}$

\section{A- Hâşiyesi'nin Genel Özellikleri}

\section{Hâşiyenin Nüshaları}

Üzerinde inceleme yaptığımız el-Atufí’ye ait Keşşâf hâşiyesinin Türkiye Kütüphaneleri veri tabanında kayıtlı sekiz adet nüshası vardır. Tespit edebildiğimiz altı nüshanın üzerinde yazan isimler şu şekildedir:

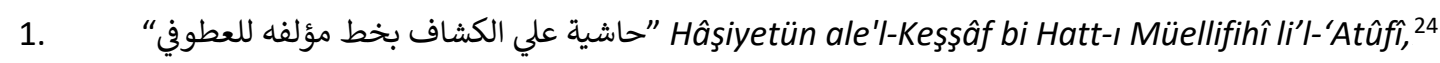

2. "حاشية علي الكشاف للعطوفي", Hâşiyetün 'ale'I-Keşşâf li'l-'Atûfi,,25

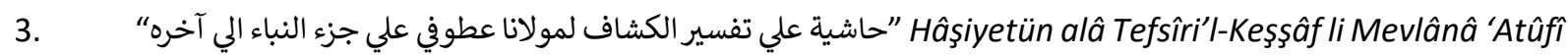
'alâ Cüzi'n-Nebei ilâ Âhirihî, ${ }^{26}$

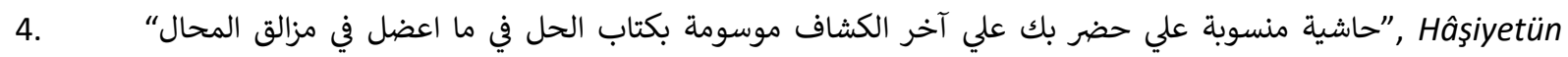
Mensûbetün alâ Hıdır Bek alâ Âhiri'l-Keşşâf, Mevsûmetün bi Kitâbi'l-Halli fî mâ E'dale min Mezâliki'l-Mahal, el-Atûfî, Hâşiyetün alâ Tefsîri'I-Keşşâf li Mevlânâ 'Atûfî 'alâ Cüzi'n-Nebei ilâ Âhirihî,, ${ }^{27}$

5. كتاب الحل في شرح آخر الكشاف لآحقر العلماء عطوفي" Kitâbü'l-Halli fi Şerh-i Âhiri'l-Keşşâf li Ahkari'I-Ulemâi Atûfi, ${ }^{28}$

6. عطوفي علي الكشاف"Atûfí ale'l-Keşşâf, ${ }^{29}$

7 ve 8. nüshalar Hâşiyetün ale'I-Keşşâf, ${ }^{30}$ Hâşiyetü'I-Atûfí ale'I-Keşşâf ${ }^{31}$ şeklinde isimlendirilmiştir.

\footnotetext{
${ }^{20}$ ismail b. Muhammed, el-Bâbânî, el-Bağdâdî, Hediyyetü'I-Arifîn Esmâü'I-Müellifîn ve Âsâru'I-Musanifîn, I, s. 346.

${ }^{21}$ Ömer b. Rıza Kehhâle, Mucemü'l-Müellifîn, IV, s.101.

22 Süleymaniye ktp., Cârullah Kitaplığı, Risale fi Beyâni Tefsîr-i Kavlihî Teâlâ Fe-Suhkan y.y., ts.. 1-6 vr.; Süleymaniye ktp., Giresun yazmaları, Hâşiye ala Tefsîr-i Kavlihî Teâlâ Fe-Suhkan li-Ashabi's-Sa'ir, y. y., t.s., 1-7 vr.; Süleymaniye ktp., Giresun yazmaları (tüyatok), Hâşiye alâ Tefsîr-i Kavlihî Teâlâ Fe-Suhkan li-Ashabi's-Sa'îr, y. y., t.s. $1^{\mathrm{a}}-7^{\mathrm{b}} \mathrm{vr}$.

${ }^{23}$ Bkz. Atûfi, Hâşiye Alâ Tefsîr-i Kavlihî Teâlâ Fe Suhkan Li Eshâbi's-Saîr: 1a-7b vr, 9 satır, nesih, krem renkli filigranlı, kenarları meşin, arka kapağı kopuk, şirazesi dağınık, mukavva kaplı bir cilt içindedir. Bu risale, içinde 11 risale bulunan (140 vr.lık) bir risaleler mecmuası içinde yer almaktadır. Mülk süresi 5-12 ayetleri bağlamında Kâdı Beydâvî (ö. 685)'nin görüşlerini açıklama, eleştirme ve araştırmasını içermektedir. Beydâvî, el-Mülk 67/11 ayetinde tağlîb sanatının olduğunu, tağlîbin de îcâz, mübâlağa ve ta'ıîl için var olduğunu kısaca ifade etmesi üzerine, talebeler Atûfi'den tağlîb ve sebeplerini açıklamasını isterler. Bu sebeple "fe suhkan li ashabi's-saîr" risalesi kaleme alınır. bkz. Tuğrul Tezcan, "Merzifonlu bir Osmanlı âlimi olarak el-Atufî ve Fesuhkan li Ashabi'sSeîr Risâlesi", I, s. 293-301.

${ }^{24}$ Süleymaniye Ktp, Reisu'I-Kuttâb, nr.927, 197 vr.

${ }^{25}$ Süleymaniye Ktp, Yeni Camî, nr.144/1, 206 vr.

${ }^{26}$ Süleymaniye Ktp, Şehid Ali Paşa, nr.263., 223 vr.

${ }^{27}$ Süleymaniye Ktp, Amcazâde Huseyn, nr.69, 208 vr.

${ }^{28}$ Süleymaniye Ktp, Dâmad Ibrahim, nr. y., 128 vr.

${ }^{29}$ Murad Molla Ktp, Murad Molla, nr. 288 (yeni nr.199),104 vr. Bu nüshanın üzerindeki kitap ismi müstensihe ait değil, muhtemelen kataloglama esnasında yazılmışır.

${ }^{30}$ Byz. Devlet Ktp, Bayezid, nr.y., 201 vr.

${ }^{31}$ Byz. Devlet Ktp, Veliyyüddin Efendi, nr.941,77 vr.
} 
Yukarıda adı geçen nüshalardan birincisinin müellif hattı olduğu, ikinci (ö.1134/1721) ve üçüncü nüshaların da (ö.1130/1717) müellifin vefat tarihine (ö.948/1541) en yakın nüshalar olmaları sebebiyle gerektiğinde mukabele yapmak için incelemeye esas alınmıştır.

\section{Müellif Nüshasının Özellikleri}

Müellif nüshasının ilk etapta göze çarpan hususları şöyledir: Nüshanın cild kapağından sonraki ilk boş sayfanın sağ üst köşesine sonradan yazıldığını düşündüğümüz Tefsîru Sûre-i Amme şeklinde bir isim vardır. Hemen altında Hâşiyetün ale'I-Keşşâf bi-hatti müellifihi li'I-Atûfí, sene otuz iki şeklinde nüshanın müellif hattı ile yazılmış orijinal nüsha olduğuna işaret eden yazı vardır. Burada geçen tarih, eserin telif tarihi değil temellük tarihi olabilir. Çünkü ferağ kaydında telif tarihi müellif tarafından açık bir şekilde (h.927/m.152021) ifade edilmiştir. Aynı sayfanın alt kısımlarına doğru bu nüshanın bir dönem sahipliklerini yapmış olan şahıslara ait temellük kayıtları ile bu kitabın sâbık Reisu'I-Küttâb Mustafa tarafından vakfedildiğine dair mühür mevcuttur.

Hâşiye her varakta on beş satır olacak şekilde nesih hattıyla yazılmış 197 varaktır. Dışı kırmızı-kahverengi karışımı bir tonda deri kaplı, cildinde lisan ve cildin ön kısmında motif bulunmaktadır.

Ferağ kaydında müellif, "Fakir ve hakir kul Âtûfi, 927/1520-21 senesi Muharrem (Aralık-Ocak) ayında Perşembe günü kuşluk vaktinde Allah'ın lütfuyla te'lîfini tamamladı" notunu düşmüştür. ${ }^{32}$

Müellif nüshasında bütün nüshalarda olduğu gibi hâşiyeden sonra bir 'tetimme'ye yer verilmiştir. Bu tetimmede besmeleyi bereket, uğur sayarak başlamanın iki duruma önemle işaret ettiğine değinilmiştir. Birincisi, genel yaratıcı, tam rahmet edici, fâzıl merhametlilik, kapsayıcı terbiyecilik, kâmil sahiplilik vb. vasıflara sahip mevlâya karşı kulun ta'zîm etmesi. ỉkincisi de kulun, atılmış sudan yaratılmış nefsini Allah'a tevazu göstererek ve saygı duyarak, kulluğunu ve acizliğini düşünerek hakîkî menzillerden bir menzile indirmesidir. ${ }^{33}$

İncelemede esas aldığımı üç nüshadan sadece Yeni Camii koleksiyonundaki nüshada 'tetimme'den sonra "Necâtü'I-Akabât" isimli, Sultan Süleyman Hanın baş harfleriyle başlayan, akrostiş tarzlı şiir bulunmakta, ${ }^{34}$ ayrıca 'tetimme'nin sonunda şerhin tamamlanma tarihi, bir beyitle ifade edilmektedir. ${ }^{35}$

\section{Atûfí'nin Keşşâf Hâşiyesi Üzerine Yapılan Çalışmalar}

Atûfî'nin Keşşâf hâşiyesi üzerine yoğunlaşmış, henüz yapılmış ve yayımlanmış müstakil bir çalışma bulunmamaktadır. Osman Kara "Osmanlı’da Tefsir Hâşiyesi Geleneği: Atufî Örneği” başlıkı bir makale yazmış, bu makalede Keş̧̧âf hâş̧iyesi üzerine mahdut bir değerlendirme sunmuştur. ${ }^{36}$ Makalesinde ağılıklı olarak Mir'âtü't-Te'vîl'e yer veren Kara, iki hâşiyeden hareketle 'Atûfî'nin hâşiyeciliğini tesbit etmeye çalışmıştır. Hal bu ki Atûfî'nin bu iki hâşiye örneğinden başka "Hısnü'I-Ayati'I-Izam fi Tefsiri Evâili Sûreti'I-

\footnotetext{
${ }^{32}$ Atûfî, Hâş̧yetün ale'I-Keşşâf bi Hatt-ı Müellifihî li'I-Atûfí, vr.197'b

${ }^{33}$ Atûfî, Hâşiyetün ale'I-Keşşâf bi Hatt-ı Müellifihî li'I-Atûfî, vr.194a-b

${ }^{34}$ Atûfi, Hôşiyetün 'ale'I-Keşşâf li'I-'Atûfi, vr. 194'-202 ${ }^{\mathrm{b}}$

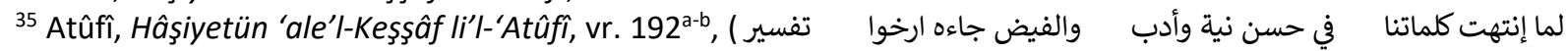
Bu şiirde yer alan cümlelerin her birinin rakamsal değeri ‘927’ dir. Dolayısıyla şerhin tamamlanma tarihi olan (h.927/1520-21 tarihine işaret etmektedir.)

${ }^{36}$ Bkz. Osman Kara, "Osmanlı'da Tefsir Hâşiyesi Geleneği: Atûfî Örneği", sayı 9, V., s. 60-62.
} 
En'am" 37 isimli müstakil bir tefsir risâlesi ile "Hâşiye ala Tefsiri Kavlihi Tealâ Fe-Suhkan li-Eshabi's-Sair" 38 isimli Beydâvî hâşiyesi bulunmaktadır. Bu iki risaleden birincisi müstakil tefsir çalışması olduğu için hâşiye kapsamında incelenmeye dahil edilmemiş olabilir. Ancak ikinci risâle, Beydavî’nin ilgili ayet üzerine yaptığı tefsire hâşiye mahiyetindedir. Bu sebeple değerlendirmeye alınması gerekirdi. Kara'nın çalışmasında bu risalelere "Atûfí'nin eserleri" kısmında da yer vermediği görülür. Netice-i kelâm, müellifin şerh ve hâşiyelerine ve Keşşâf hâşiyesi üzerine daha ayrıntılı çalışmaların yapılması gerekmektedir. En-Nebe süresi hâşiyesiyle sınırlı olan bu çalışmayı hâşiyenin tamamını kapsayan bir inceleme ile taçlandırma sürecinde olduğumuzu da bu vesile ile belirtmek isteriz.

\section{Hâşiyenin Yazılış Sebebi}

Atûfî, Keşşâf hâşiyesini yazma gerekçesini şöyle ifade etmiştir: "Keşşâf'ın son bölümü üzerine hâşiyeler yazıldı. Çünkü son bölüm Müslümanların en çok ihtiyaç hissettikleri, dinin direği olan namazda en çok okunan sûrelerin açıklanmasına dair olan kısımdır. Bu sebeple bu kitap, "el-Hallü fî mâ e'dale min ba'di'lmahal/ min mezâlikı'l-Mahal ${ }^{39}$ (anlaşılması güç / kaygan zeminlerden bazı kısımları açıklamak) şeklinde isimlendirilmiştir." 40 ikinci bir gerekçe olarak kendi şahsı için dönemin halifesinden dua talep etmek ${ }^{41}$ niyetiyle bu çalışmayı yaptığının altını çizmiştir. ${ }^{42}$

Bu iki husus, yani toplumun ihtiyaç duyduğu konulara yönelik çalışmalar yapmak ve sultanların maddî ve manevî lütuflarına mazhar olmak niyetiyle telifte bulunmak, genel olarak şerh, hâşiye, ta'lik vb. çalışmaların yapılma sebepleri arasında sayılmıştır. ${ }^{43}$

\section{Hâşiyenin Müellife Âidiyeti}

Müellife nisbet edilen Keşşaf hâşiyesinin âidiyet sorunu yaşamadığını söyleyebiliriz. Eserleri hakkında bilgi veren eş-Şakâiku'n-Nu'mâniyye fí Ulemâi'd-Devleti'l-Usmâniyye isimli eserden ${ }^{44}$ Hediyyetü'l-Arifîn ve Mu'cemü'l-Müellifîn' ${ }^{45}$ kadar birçok tabakât kitabı müellifin Keşşâf üzerine yapılmış hâşiyesinin olduğundan bahseder. ${ }^{46}$ Ayrıca hâşiyenin bir tanesi müellif nüshası olmak üzere toplam sekiz adet nüsha

\footnotetext{
${ }^{37}$ Süleymaniye ktp., Ayasofya nr.396, 19 vr.; Ayasofya nr.399, 51 vr., bu risale üzerine Tuğrul Tezcan, "Hayreddin Hızır Atûfî ve Hısnu'l-Âyati'l-I'zâm fî Tefsir-i Evâil-i Sûreti'l-En'âm Risalesi” isimli bir tebliğ hazırlamıştır. Bkz. “Hayreddin Hızır Atûfî ve Hısnu'I-Âyati'l-I'zâm fî Tefsir-i Evâil-i Sûreti'l-En'âm Risalesi”.

${ }^{38}$ Risalenin üç adet nüshası mevcuttur. Bunlar, Süleymaniye ktp., Giresun Yazmalar nr.3572, vr. $1^{\mathrm{a}}-7^{\mathrm{b}}, \mathrm{Carullah}^{\mathrm{B}}$, nr. 2121, vr.1-6; Esad Efendi nr. 91, vr.236-237' nüshalarıdır.

${ }^{39}$ Müellifin şerhe yöneldiği yerleri ifade eden bu ifadelerin her ikisi de haşiyelerde mevcuttur. Şehid Ali Paşa 263 (vr. $3^{\text {a }}$ ) ve Amcazâde Hüseyin 69 (vr. $4^{\text {b }}$ ) nolu nüshalarda fîmâ a'dele min mezâliki'l-mahal, Yenicâmi 144/1

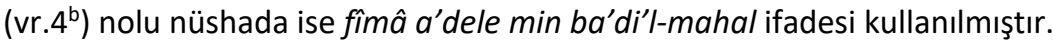

${ }^{40}$ Atûfî, Hâşiyetün ale'l-Keşşâf bi Hatt-ı Müellifihî li'l-Atûfî, vr. $3^{\text {b }}$

${ }^{41}$ Eserin dua bölümünde Osmanlı padişahlarını büyükten küçüğe doğru sıralamış en küçükleri olarak Sultan Süleyman'ı zikretmiştir. O esnada hayatta olan padişah olması münasebetiyle kendisinden dua beklenen Halifenin Sultan Süleyman olması muhtemeldir. Reisü'l-Küttab, vr.2b; "Necâtü'l-Akabât" isminde Akrostiş tarzında (Aşağıya doğru her beytin baş harfi Sultan Süleyman Han'ın isminin harfleriyle başlamaktadır.) 14 beyitten oluşan bir risaleyi yine Sultan Süleyman Han'a ithafen yazmıştır. Bu risale Yeni Camii nüshasının son kısmında bulunmaktadır. Bk. Atûfî, Hâşiyetün 'ale'l-Keşşâf li'l-'Atûfî, vr.194a-202a

${ }^{42}$ Bk. Atûfî, Hâşiyetün ale'l-Keşşâf bi Hatt-ı Müellifihî li'l-Atûfî vr. $3^{\text {b }}$

${ }^{43}$ Bu tür çalışmaların birçok sebebi olabilir. Şerh ve Hâşiyelerin dibace kısımlarında müellifin maksadını yansıtan "alim bir dostumun/talebelerimin/bu kitabı okuyanların (meslektaşlarımın), devlet adamının (...) bu metnin/kitabın meselelerini açmam, zor muğlak kısımlarını açıklamam, ıstılahlarını tarif etmem istikametindeki ısrarlı arzularını yerine getirmek için bu eseri telif ettim." İsmail Kara, "Unuttuklarını Hatırla! Şerh ve Hâşiye Meselesine Dair Bir Kaç Not", ss. 1-67, 9.

${ }^{44}$ Aḥmed b. Mușțafa Taşköprîzâde, eş-Şekâiku'n-Nu'mâniyye, I, 249.

45 'Umar Rıḍâ Kehhâle, Mu'cemu'I-Muellifîn Terâcimu Mușannifiyyi'l-Kutubi'I-'Arabiyyeti, II, 307.

${ }^{46}$ Bâbânzâde İsmâî̀l Paşa el-Bağdâdî, Hediyyetu'l-'Ârifîn Esmâ'u'I-Muellifîn ve Âsâru'l-Müsannifîn, 346.
} 
bugün Türkiye Kütüphaneleri veri tabanında kayıtlı halde bulunmaktadır. Dolayısıyla gerek tabakât kitaplarının işaret etmeleri gerekse işaret edilen eserlerin mahtût olarak elimizde bulunması, ayrıca nüshalar içinden bir tanesinin de müellif nüshası olduğuna işaret edilmesi, hâşiyenin müellife aidiyetini ispat sadedinde yeterli olacaktır.

\section{B- Hâşiyenin Yöntemi}

Müellif, hâşiyesini konu başlığı tayin etmeden, Nebe'den Nâs sûresine kadar açıklamayı önemli gördüğü kısımlar üzerine şerh yapmak süretiyle oluşturmuştur. Hâşiyesine ilâve etmeyi istediği açıklamalarını ise sonradan 'Tetimme' başlığı altında zikretmiştir. Hâşiyesini yaptığı eserin sahibi Zemahşerî için "Müsannif", "Sahibu'I-Keşşâf" isimlerini kullanmış, onun görüşlerine "kavlühü" (قوله) ile işaret etmiştir. Kendisine ait açıklamalara ise "ya’nî" (يعني), "ekûlü" (اقول), “ürîdü bihî” (اريد به), "ey" (ائ) vb. ifâdeler ile başlamış bazen de bu ifâdeleri kullanmaksızın doğrudan açıklama yapmıştır. ${ }^{47}$ Hâşiyede lafız ve cümle tahlilleriyle, itikâdî konulardaki ikaz mahiyetindeki açıklamalar yoğunluk oluşturduğundan inceleme, 'tefsîrî ve irşâdî açıklamalar' başlıkları altında sürdürülecektir.

\section{Tefsir Nitelikli Açıklamaları}

Dil ve Belâgat ağırlıklı açıklamaların ağırlıklı olduğu bu bölümde müellif, Ulûmu'l-Kur'ân (Mekkî-Medenî, Kıraat) konularına kısaca temas etmiş, kelâmî, tasavvufî ve ilmî tefsir tarzında açıklamalara da yer vermiştir.

\subsection{Dil ve Belâgatla İlgili Açıklamaları}

Müellif, kapalı olduğunu düşündüğü, müsannifin "aslühû" (عصله) diyerek açıkladığı kısımları, kelime, cümle yapısı, edatlar ve mânâya etkileri ve belâgatla ilgili incelikleri yönlerinden herhangi bir tertip gözetmeden açıklamaya çalışmışır.

\subsubsection{Lâfız Tahlili}

Hâşiyenin tamamında önce müsannifin tefsirinden bir bölüm zikredilmekte sonra da müellifin açıklaması gelmektedir.

Müsannif, "amme yetesâelûn" ifadesindeki "ammâ" (عما) nın nasıl ammeye (عم) dönüştüğünü: "harf-i cerre, istifhâm (soru eki) 'mâ' (م) nın dâhil olmasıyla oluşmuştur" ifadesiyle açıklamış müellif de ilgili açıklamayı şöyle şerh etmiştir: "Ben derim ki 'ammâ' (عما) iki kelimedir. Birisi 'an' (عن) diğeri soru eki olan 'mâ' (مان) dır. Zamîrin tevhîd edilmesi ve erilliği sebebiyle bu kelimeden 'elif' (I) harfi düşürülmüş ve 'amme' (عمّ) ('c) olmuştur. Ayrıca musannifin ifadesinde asıl ancak zikredilen şeye veya lafza itibar iledir" 48 diyerek musannifinin açıklamasında dikkat ettiği hakikatin altını çizmiştir. Zemahşerî”nin kullandığı "Fenkale" ${ }^{49}$ tarzındaki üslûbun müellif tarafından da benimsediği görülür. Meselâ, musannifin, "alâ ennehû harfü cerrin" ifadesini, yani diyerek şöyle açıklamıştır:

Ennehû/ انه daki zamir ammâ/ Lماعِlafzına döndüğünde harfü'l-cerrin istifhâm mâ'sına birleştiği ve harfü'lcerr'in ammâ/ عم lafzının bir parçası olduğu nasıl anlaşılır denilse; onu iki açıdan cevaplarım/açıklarım. Birincisi: Onun mânâsı harfü'l-cerr'in ve istifhâm mâ'sını cem etmiştir. Bu ifade biçiminin dengi olan cümle şudur: "Uzaktan, yanında adam olan bir yaşlı gördüğünde ve o ikisi nedir? (بما هما) diye sorduğunda şöyle

\footnotetext{
${ }^{47}$ Atûfî, Hâşiyetü ale'I-Keşş̂ff bi Hatt-ı Müellifihi li'l-'Atûfí, vr.5 $5^{\mathrm{a}}-7^{\mathrm{a}}$

${ }^{48}$ Hayreddin Hıdır Atûfî, Hâş̧iyetü ale'I-Keşşâf bi Hatt-ı Müellifihi li'I-'Atûfi, vr. $3^{\text {a }}$

49 “in gulte fegultü” (ان قلت فقلت); “in gultüm fe gulnâ/fe negûlü” (ان قلتم فقلنافنقول) vb. ifade biçimleri için kullanılan bir tabirdir.
} 
cevap verilir: $\mathrm{O}$ ikisi at süren bir adamdır. Diğeri ise, bir muzâf takdir etmektir. Takdîrî olarak getirilen muzâf'ın bir cüz'ünün istifhâm mâ'sına birleşmiş harf-i cerr olması gerekir.

Müellif, "kıl” (قيل) lafzıyla, yâni temrîz sîgasıyla50 soruya verilmiş bir başka cevabı da nakleder. "Ennehû" (انه) da "ammâ" (عما) lafzındaki "an" (عن) harfü'l-cerrine dönen bir âid zamirin olması caizdir. Erillik de zikredilen şeye veya habere (النباُ) itibar iledir."

Müellif, müsannifin 'amme' (عم) kelimesinin aslı, harf-i cerr'in, istifhâm [soru eki] 'mâ' (مام) ya dâhil olmasıdır" ifadesindeki, "alâ mâ el-istifhâmiyye" kısmıyla neyi kastettiğini açıklamak üzere istifhâm 'mâ' (م) sının cümleye kattığı anlamdan bahseder.

"Amme" (عمَّ), kelimesindeki "mâ" (م) ister hakîkî, isterse şeklen soru edâtı olan "mâ" olsun burada sadece 'ta'zîm' içindir. Hasan'ın şiirinde sövgüye soyunan kişinin yaptığı işi mücerret anlamda tahkir etmek veya kınama işinin alçaklığını ta'zîm etmek gibi ${ }^{52}$ bir anlama sahiptir. ${ }^{53}$

Müellif, bazen müsannifin edatlarla ilgili açıklamasını naklettikten sonra kendi görüşünü kısaca belirtmekle



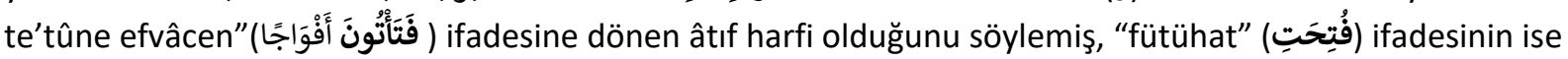
işin vukû bulacağını göstermek için mâzî sîgasıyla geldiğini belirtmiştir. Ona göre kastedilen gelecektir. Âhiret halleri ilgili birçok durumda yüce Kur'ân'ın üslûbu böyledir." Müellife göre ise "bu durumda vâv'ın (و) hâliyye olması câiz olur ve en seçkin görüş odur." 55

Bazen de açıklamaları müsannifin görüşüne itiraz mahiyetinde olabilmektedir. Meselâ, Müellif, Zemahşerînnin "sümme kellâ seya'lemûn (ثم كلا سيعلمون) ifadesindeki "sümme" (ثم) edâtı ile ilgili açıklamalarını daha anlaşılır kılmak için Ömer en-Nesefî'nin (ö.537/1142) et-Teysîr ${ }^{56}$ isimli eserinden de istifade ederek katkı sunmuştur. Zemahşeri'ye göre "sümme" (ثم) nin anlamı: "sadece ikinci vaîd'i birincisinden daha şiddetli ve belî̆g bir şekilde hissettirmektir. Işs'âr şeklinin en kuvvetlisi olan "sümme" (ثم) burada sadece inbar içindir." ${ }^{77}$ Müellif ise müsannifin ifadesini şöyle açıklamıştır:

"Sümme" haberde terâhî, sıralama [tertib] içindir. Sanki şu cümlede olduğu gibidir. "Bir haber verdim sonra [ [م [ bir diğer haberi verdim" şeklinde söylenildiği gibi. Birinci haber aynıyla söylendiğinde dinleyenin aklına birinci haberden daha önemli ve konuşmaya değer bir şey olmadığı gelir. Ve boyun eğmek zorunlu hale gelir. Bu sebeple buna "ihbârî sümme" denir. Benzeri kullanım Kur'an'da az değildir. Müellif, “...sümme kâne mine'l-lezîne âmenû..." (ثم كان من اللذين امنوا) ayetinde de benzer bir durum olduğunu, Teysîr sahibinin de bunun inbârî tertib olduğunu, vucûd tertîbi olmadığı yönündeki görüşünü nakleder. ${ }^{58}$ Bu ayetle ifade edilen inbârî tertib, "sonra size bunun mü'min kişi için olduğunu haber verdi" şeklindedir. ${ }^{59}$

\footnotetext{
${ }^{50}$ Hadis metninde bir kelimenin yanlışlığına veya bir rivayetin zayıflığına işaret etmek için kullanılan terimdir. Mânen rivayetlerde de kullanılır." Bkz. Ahatlı, Erdinç, "Temrîz", s. 433-34.

${ }^{51}$ Atûfî, Hâş̧iyetü alâ Tefsîri'l-Keşşâf li Mevlânâ 'Atûfi 'alâ Cüzi'n-Nebei ilâ Âhirihî, vr. 4"-b; Atûfî, Hâşsiyetü ale'lKeşşâf bi Hatt-ı Müellifihi li'I-'Atûfi, vr. $3^{\mathrm{a}}-4^{\mathrm{b}}$

${ }^{52}$ Hasan b. Münzir'e ait olan şiirde "kötü adam külün içinde debelenen domuz gibi bana hangi sebepten sövüyor" denmektedir. Ayrıntılı bilgi için bkz. Ez- Zemahşerî, El-Keşşâf, IV, s. 670.

${ }^{53}$ Atûfî, Hâşsiyetü ale'I-Keşşâf bi Hatt-ı Müellifihi li''-'Atûfí, vr. $4^{\mathrm{b}}$

${ }^{54}$ En-Nebe 78/19.

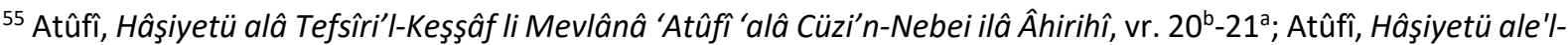
Keş̧̧âf bi Hatt-ı Müellifihi li'l-'Atûfî, $17^{\text {b }}$

${ }^{56}$ Eserin tam adı et-Teysîr fî (ilmi)'t-Tefsîr'dir. Ebu Mansur el-Maturîdî'nin Te'vîlâtü'l-Kur'ân'ı ile Kuşeyrî'nin İşârât'ı ana kaynak olarak kullanılmıştır. Ayşe Humeyra Aslantürk, "Necmeddin Nesefi", XXXII, 2006, ss. 571-573.

${ }^{57}$ ez-Zemahşerî, Tefsîru'I-Keşşâf, IV, s. 671.

${ }^{58}$ Atûfí, Hâşiyetü alâ Tefsîri'l-Keşşâf li Mevlânâ 'Atûfi 'alâ Cüzi'n-Nebei ilâ Âhirihî, vr. $7^{\mathrm{b}}-8^{\mathrm{a}}$

${ }^{59}$ Atûfî, Hâş̧yetü ale'I-Keşşâf bi Hatt-ı Müellifihi li'I-'Atûfî, $6^{\text {a }}$
} 
Müellif, Zemahşerî’nin delil olarak sunduklarını dilin imkânı nisbetinde eleştirmiştir: Yukarıdaki konunun bir devamı olması sebebiyle daha iyi anlaşımaya imkan vereceğinden şu örneği vermemiz isabetli olacaktır: Zemahşerî, elifi hazfedilen "ammâ" (عما) lafzına bir örnek olsun diye şair Hassan'dan ${ }^{60}$ sunduğu delil, Atûfi'ye göre maksadı açıklayıcı türden değildir. Çünkü burada harfü'l-cerre dahil edildiğinde elifin düşmesine örnek olması gerekirken düşmemiştir. ${ }^{61}$

$$
\text { وتلقاه على ما قام يشتمني لئيم ... كخنزير تمرغ في رماد }
$$

Ancak Zemahşerî, yaptığı işin farkında olduğunu şu ifadeleriyle gösterir. "Çoğu kullanım "elif"in (I) hazfi üzerinedir. Örneğini verdiğim şiirdeki kullanım ise azdır. Bu istifhâmın mânâsı bir işi büyük göstermektir. Yani sanki şöyle söylemiştir: "an eyyi şey'in yetesâelûn" (عن اي شأن يتساءلون) Hangi durumu birbirlerine soruyorlar? ${ }^{62}$

Müellif, Zemahşerî'nin kastettiği mânâyı işaret eden açılkamalarda bulunmuştur. Meselâ "tefhîmü'ş-şe'n" [durumu büyük göstermek] ifadesindeki şe’n kelimesiyle müsannifin ne demek istediğini, “...ayetin siyâkının delâleti sebebiyle şe'n ile ba's yâni Allah'ın mevtâyı dirilteceği veya ölünün diriltilişi ifade edilmek istenmiştir." 63 Zîra Allah Teâlâ’nın siyakta söylediği " إِنَّ يَوْمَ الْفَصْلِ “ 每 65 ayetine kadar Allah Teâlâ'nın ba's işine delalet eden deliller barındırmaktadır ${ }^{66}$ sözleriyle açıklamıştır.

Müellif, Zemahşerînin vakıf ve ibtidâ konusundaki açıklamalarını da, vakıf ve ibtidânın cümleye etkisi bakımından incelemiştir. Zemahşerî, "amme" (عم) ifadesinin "ammeh" (عمد) şeklinde sekte ha'sı ile de okunduğunu, vaslın vakf yerine ya da önce vakfedip sonra zamirden başlayarak ibtidâ edilebileceğini ỉbn Kesîr kıraatından naklederek ${ }^{67}$ açıklamıştır. Müellif ise, "kâilin şunu söylemesi", ya da "denilse" gibi ifadelerle farklı ihtimallere imkân veren görüşlerin olabileceğini göstermiş, kendi görüşünü de açıklamıştır.

Görünüşe göre hâu's-sekt'te vakıf yapmak iktizâ ederse o zaman takdîren cümlenin "yetesâelûne ammeh yetesâelûne ani'n-nebei" (يتساءلون عمه يتساءلون عن النباء) şeklinde olması gerekir. Denilse ki "yetesâelûn" (يتساءلون) ifadesinin "amme" (عمد) den sonraya te'hîr edilmesi gerekir. Çünkü istifhâm mâ'sı cümle başında gelir. O zaman şöyle cevap veririm: "istifham mâ'sı cümlenin başına ancak soru anlamından soyutlandığında gelir. "ما ليلة القدر ، ما الحاقة" ayetlerinde olduğu gibi.68

\subsubsection{Cümle Tahlilleri}

Müellif, "fe in gulte zikra ibn Keysân" (فإن قلت ذكر إبن كيسان) şeklindeki müsannife ait ifadenin (ذكر إبن كيسان)

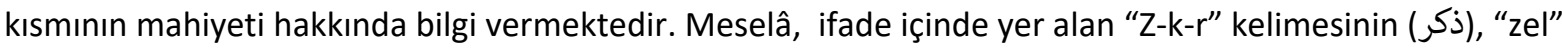
(ذ) harf ötre, "kef" (كُ) harfi de kesralı olarak "zükira" (ذِكَ) şeklinde okunduğunu ve cümle içinde mef'ûl durumunda bulunduğunu söylemiştir. ${ }^{69}$

\footnotetext{
${ }^{60}$ Bu şiirin sahibi olarak ifade edilen kişi Hassan ibn Münzir'dir. Bkz. ez-Zemahşerî, Tefsîru'I-Keşşâf, 670.

${ }^{61}$ Atûfî, Hâşiyetü alâ Tefsîri'l-Keşşâf li Mevlânâ 'Atûfí 'alâ Cüzi'n-Nebei ilâ Âhirihî, $4^{b}$

62 ez-Zemahşerî, Tefsîru'I-Keşşâf, 670.

${ }^{63}$ Atûfî, Hâşiyetü ale'I-Keşşâf bi Hatt-ı Müellifihi li'I-'Atûfí, vr.4 ${ }^{\mathrm{a}}$

${ }^{64}$ En-Nebe 78/6.

${ }^{65}$ En-Nebe 78/17.

${ }^{66}$ Atûfî, Hâş̧iyetü alô Tefsîri'l-Keşşâff li Mevlânâ 'Atûfí 'alâ Cüzi'n-Nebei ilâ Âhirihî, vr. $5^{\mathrm{a}}$

${ }^{67}$ ez-Zemahşerî, Tefsîru'I-Keşşâf, 671.

${ }^{68}$ Atûfî, Hâşiyetü alâ Tefsîri'I-Keşşâf li Mevlânâ 'Atûfí 'alâ Cüzi'n-Nebei ilâ Âhirihî, , vr. 7a-b

${ }^{69}$ Atûfî, Hâş̧iyetü ale'l-Keşşâf bi Hatt-ı Müellifihi li'I-'Atûfî, $16^{\mathrm{a}}$
} 
Müsannif, "ve cennâtin elfâfa" (و جنات الفافا) ifadesini açıklarken "elfâfâ" (الفافا) kelimesinin çoğul geldiğini fakat tekil kullanımlarının da var olduğunu söyler ve delil olarak, i̇klîd sâhibinin şâir el-Hasen b. Ali etTûsî'den aldığı bir şiiri nakleder. Müellif ise müsannifin "lef" (لف) kelimesini açıklamak için şiirden seçtiği “ayşun mu'digun" (عيش مُنْدِقِق) ifadesini ${ }^{70}$ açıklar:

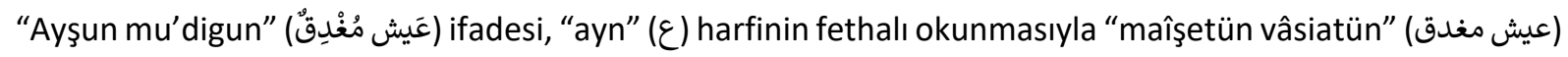
demektir. "Ayn" (ع) harfinin kesralı okunmasıyla "ve'l-îyşetü" (والعيشة), "ve'l-meâş" (و المعاش), ve'l-meîşetü kelimelerinin mânâları birdir. "El- mu'dig" (او المعيشة) (الغدق) (المُغْدِق) ise, "el-ğadeg"imesinden ism-i faildir ve hemzesi sayrûret için olan fiilerdendir. "Dal ve kaf" harflerinin fethalı okunması halinde "el-ğadeg” (الغَدَقَق kelimesi, "bol su" anlamına gelir. ${ }^{71}$

Bu konu ile alakalı bir başka örnekte müsannifin “vekezzebû bi âyâtinâ kizzâbâ” (وكذبة) (وكبوا بأياتا كذابا) ayetiyle ilgili olarak söylediği “şayet 'kizzâben' kelimesini, 'mükâzebeten' (مكاذبة) şeklinde anlasan"72 ifadesine yöneliktir.

Yani sen onu "fâale" (فاعل) babından masdar yapsan, masdariyye bir ifade üzerine nasb olarak gelmesi halinde "fe kâzibû mükâzebeten" caiz olur. Hal üzerine nasb olarak gelse bu durumda da "ve kezzebû bi âyâtinâ mükâzibîn" şeklinde olur.

Müellif, "ani'n-nebei'l-azîm” ifadesindeki "en-Nebe” (النباء) kelimesinin cümle içindeki yerinden bahseder.

"En-Nebe”, haberdir. Ancak kastedilen "mühbirun bih" yani ba's'dir. Ba's kelimesinin fail için veya mef'ûl için olmasına bağı̆ı olarak "muhbirun anh" Allah Teâlâ veya mevtâ olabilir. ${ }^{73}$

Müellif, müsannifin üstü kapalı olarak ifade ettiği "yetesâelûn" ifadesindeki izmâr meselesi üzerinde duruyor. Müsannif bu konuyla ilgili “'yetesâelûn' izmâr üzere gelmiştir. Çünkü sonraki "ani'n-nebei'l-azîm" cümlesi bu izmârı açıklıyor" cümlesini yeterli bulmayarak farklı görüşlerle ve yönlerle "amme yetesâelûn" ifadesini ele alır.

Birincisi: "Yetesâelûn" ifadesinde izmârın varlığı mevzuunda büyük alimlerin görüşüne yer vermesidir. "Bazı alimler "amme" kelimesinde, izmârın amil olduğunu söylemişler ve takdir onlara göre "amme yetesâelûne yetesâelûne" (عم يتساءلون يتساءلون) olmaktadır.

íkincisi: "Amme yetesâelûne" (عم يتساءلون) ifadesinin zâhirinde bazılarına göre, "ha-i sekt" gereklidir. O zaman ifade (يتساءلون عمه يتساءلون عن النباء) şeklinde olmalıdır.

Üçüncüsü: Şayet, "yetesâelûn" ifadesindeki izmârın "amme" den tehir edilmesi istifhâm mâ'sı sebebiyledir, çünkü istifhâm [soru] cümle başında gelir, denilse ben de şunu söylerim: "Soru kelimesi olan "ma"nın (م) cümle başında gelmesi ancak soru [istifhâm] anlamından soyutlandığında mümkün olur. Allah Teâlâ’nın "alhâkkatü ma'l-hâkkatü" (الحاقة ما الحاقة) veya "el-kâriatü ma'l-Kâriatü" (القارعة ما القارعة) ifadelerinde olduğu gibi. $^{74}$

Müellif, "ve mâ tünkirûnehû mine'l-ba'si ve'l-cezâi” (وما تنكرونه من البعث و الجزاء) ifâdesini zâhiren müşkil gören bazı ekâbire cevap olması için ifadeyi nahiv yönünden tahlil etmiştir.

Cümleyi sorunlu gören ekâbire göre, "mâ" (ما) mübtedâdır, "mine'I-ba'si” (من البعث) kısmı "mâ”yı açılıyor. “Müeddin" (مؤد) ise haberidir. O zaman mânâ, "ba's ve cezâ Allah Teâlấnın abesle iştigal ettiğini gösterir" şeklinde olur. Bu anlam fasit bir anlamdır.

\footnotetext{
${ }^{70}$ Ez-Zemahşerî, el-Keşşâf, IV, s. 687.

${ }^{71}$ Atûfî, Hâşiyetü ale'l-Keşşâf bi Hatt-ı Müellifihi li'l-'Atûfî, vr. $15^{\text {b-a }}$

72 Ez-Zemahşerî, el-Keşşâf, IV, s. 689.

${ }^{73}$ Atûfî, Hâşiyetü ale'l-Keşşâf bi Hatt-ı Müellifihi li'l-'Atûfî, $6^{\text {b }}$

${ }^{74}$ Atûfî, Hâşiyetü ale'l-Keşşâf bi Hatt-ı Müellifihi li'l-'Atûfí, $6^{\text {b-a }}$
} 
Bir başka açıdan "mâ" (ما), "onu inkâr ediyorsunuz"dan (تنكرونه) ibârettir. "Tünkirûnehû" (تنكرونه)

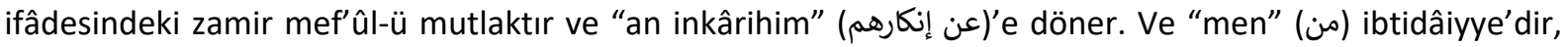

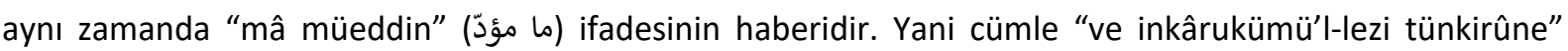
olmaktadır. Bu cümledeki inkar da Allah Teâlâ'nın abesle iştigal ettiğine veya O’nun abesle işgal ettiğinin delillerine götürür.

Müsannifin söylediği şeyi câiz gören bir grubun düşüncesi de müellife göre Allah teâlâ’nın abesle iştigal ettiğine götüren bir tevil kapısını aralamaktadır ve yine bu düşünce de fâsit bir düşüncedir.

Müsannifin kabul gören düşüncesine göre, ism-i mevsûl olan 'mâ'nın mübtedâ; 'mine'l-ba'si'nin 'mevsûle mâ'sını açıklayan kelime; 'müeddin', cümlenin haberi; 've mâ tünkirûnehû' ifadesindeki zamir de mevsûle döner. O zaman mânâ şöyle olur: "İnkâr ettiğiniz cezâ için diriliş [ba's] o zaman, "Allah Teâlâ abesle iştigal eder" şeklindeki iddianıza götürür. Yani "ba's" sizin katınızda "ba's" olduğu için değil, inkar edilen, menfi bir şey olduğu içindir. Bu durum da Allah Teâlâ'nın abesle iştigâli meselesini ilzâm etmektedir. ${ }^{75}$

Müellif, bu iddiasını bir başka ayetle destekleyerek açıklamaktadır. Bu aynı zamanda müellifin tefsirinde rivayet metodunu kullandığının bir başka göstergesidir.

Bakara 2/47. ayette iştibah (müteşâbihlik) yoktur, mânâ açıktır. Ayette dile getirilen beşâret [müjde] iman eden ve salih amel işleyen mü'minler içindir. Ayette dile getirilen müjde, zâtları [Müslüman kimliği] için değil sadece iman ve salih amelleri içindir. Bu cümledeki incelenen şey ise, sıletü'l-mevsûl'ün haber cümlesi olmasıdır. İsnad bilgisi ve sılaya taalluk, konuşmadan önce dinleyen içindir. O zaman mevsûl şu zımnî anlamla muttasıftır: Sıla mütekellim ilminde, sâmî’ de tekellümden öncedir. Mevsûl, sılasının ünvanıyla zikredilse ve mevsûlden anlaşllan illiyet hükmüyle ona hükmedilse bu unvan, mevsulü hükümle vasıflamak içindir. Meselâ, "kim dinde alimse yüceltilir" denildiğinde bu cümleden anlaşılan, dînî ilim, din ehlinin ta'zîm ve saygı göstermesi için illet ve sebeptir. Bu saygı zatları sebebiyle değil, ilimleri sebebiyledir. Bu aksi durum için de söylenebilir. ${ }^{76}$

\subsubsection{Sözcük Tahlilleri}

Müellif, Kur'an ayetlerinde geçen kelimelerin yerli yerinde kullanıldığı konusunda farkındalık oluşturmak gibi bir gayeye de hizmet edebilecek türden sözcük tahlillerine yer vermiştir. Incelemesini de rivayetle

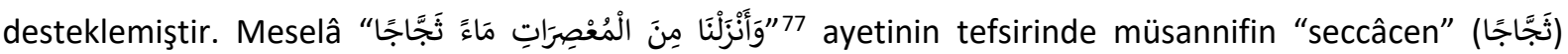
kelimesini "yesbülü garben" (يسبل غربا) ifadesiyle açıklamış, Hasan el-Basrî’den naklettiği bir rivayetle de bunu müdellel hale getirmiştir.

"Yesbülü garben" (يسبل غريا) ifadesi bir kovadan dökülürcesine suyun boşalmasını ifade etmektedir. "elGarabü" (الغرب) öküz derisinden yapılmış büyük kova demektir. Yani yağmur, suyun bu kovadan dökülmesi gibi sel halinde boşalmaktadır. Hasan el-Basrî́nin rivayetinde ${ }^{78}$ hatibin ağzından dökülen kelâm, suyun kovadan dökülmesi gibi fasılasız, akıcı ve fasih olduğundan, hatib için "müseccen" (مثجا) tâbiri kullanılmıştır. Zîra, yağmurun bulutlardan dökülmesiyle fasih bir hatibin ağzından kelimelerin akıcı bir tarzda dökülmesi arasında benzerlik söz konusudur. ${ }^{79}$

\footnotetext{
${ }^{75}$ Atûfî, Hâşiyetü ale'l-Keşşâf bi Hatt-ı Müellifihi li'l-'Atûfí, vr. $9^{b}$

${ }^{76}$ Atûfî, Hâşiyetü ale'l-Keşşâf bi Hatt-ı Müellifihi li'l-'Atûfî, vr. $9^{\mathrm{a}}$

77 En-Nebe 10/14.

${ }^{78}$ Rivayet şöyledir; Hasan el- Basrî dedi ki: “ibn Abbas Basra'da ilk öğretmendir. O mescidin minberine çıktı. Bakara ve Al-i İmran sûrelerini okudu ve harf harf tefsir etti. Ağzından kelimeler kovadan suyun dökülmesi gibi akıyordu." Ebubekir ibn Ebî Şeybe, Kitabü'l-Müsannef fi'l-Ahadîs-i ve'l-Âsâr, III, s.287.

${ }^{79}$ Atûfî, Hâşiyetü ale'l-Keşşâf bi Hatt-ı Müellifihi li'l-'Atûfî, 14ª -15
} 
Müellifin sözcük tahlîî bazen müsannifin yaptığı açıklamaları kritik eder tarzdadır. Fakat eleştirilerde saygı çerçevesinin dışına çıkılmamıştır. Meselâ, "وَّجَعَلْنَا نَوْمَكُمْ سُبَاتًا" Uykunuzu bir dinlenme (sebebi) kıldık80

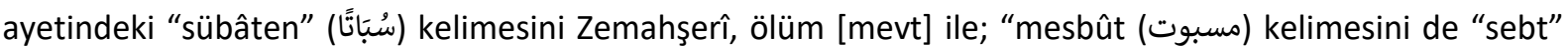
(سبت) ile aynı anlama gelen meyyit (ölü) kelimesiyle tefsir etmiş ve kesmek "el-kat'u" (القطع) anlamını ifade ettiğini söylemiştir. Çünkü uyku halinde kişi hareketten kesilmiştir. Bu yönüyle uyku [nevm] da iki ölümden birisidir. ${ }^{81}$ Müellife göre ise;

“Mesbût'un" (مسبوت), "maktû' ani'l-hareket" (مقطوع عن الحركة) üzerine yâni hareketten kesilmiş, ölü anlamında genellenmesi, sübât'ın mevt üzerine genellenmesini ve onunla tefsir edilmesini gerektirmez. Müsannif sübat'ı mevt olarak açıklamak istemesi teşbih içindir. Yani "sübâten" (سُبَاًًا), mevt [ölüm] gibidir. ${ }^{82}$

Müellif, eleştirmesine rağmen müsannifin bazı tesbitlerini teyid eden açıklamalardan kaçınmamıştır. Müsannifin, “'sübâten' (سُبَاتًا) kelimesi kalıp itibariyle 'ed-düvâü' (الدواء) yapısındadır" 83 ifadesini şu açıklamalarıyla desteklemiştir.

"Aslında bu bina kalıbında gelmesi bile sübât ile mevt arasındaki ilişkiyi sadece bir benzerlik ilişkisinden öteye taşıyordu. "Sübâtın sadece bedenî istirahat olmadığını, mevt ile ilişkisinin olduğunu ortaya koyan bir başka delil, sübâtın "ed-düvâü" (الدواء) binasında olmasıdır. Bu vezin genellikle hastalıklar için kullanılmaktadır. Hunâk, su'âl, kunâ, cüzzâm gibi. Sübâtın mevt ile tefsir edilmesine gelince, mevt hastalıkların ve bedenle ilgili musibetlerin başıdır. Dolayısıyla "bedenî rahat" olarak açıklanmasından daha evlâdır. Müellif ayrıca bir tahminde bulanarak müellifin bu benzetmesinin arkasındaki niyeti ifade etmeye çalışır. (...) Belki de müsannif sübâtı mevt ile, yakazayı hayat ile, maâşı hayat ile tefsir etmesi, ba'sı inkar etmek isteyenlere cevap vermek istemekte aşırı hırs göstermesindendir. Müsannifin bu hırsının altında sanki şu sözü yer almaktadır. "Uhrevî dirilişin benzeri dünyada iken her gün gösterildiği halde dirilişi nasıl inkar edersiniz." 84

Müellif, sözcük tahlîli esnasında rivayetlerden, lügat ve kıraat alimlerinin görüşlerinden, tefsirlerden de yararlanmıştır. Meselâ, "lâbisîne fîhâ ahkâbâ" (الابثين فيها احقابا) ayetinin tefsiri esnasında ahkâb" (احقاب)

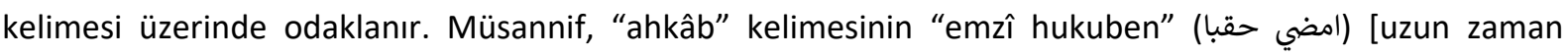
geçiririm], "esîru zemenen tavîlen" (اسير زمنا طويلا) [uzun zamandır yürürüm] ifadelerinde olduğu gibi bir anlam ifade ettiğini, "uzun bir zamandan sonra tekrar uzun bir zaman" (حقبا بعد حقب) anlamına geldiğini, bu sürenin de seksen sene olduğunun söylendiğini nakleder. ${ }^{85}$ Müellifin açıklamaları ise şöyledir:

Müsannif kelimeyi meşhur kıraatta olduğu gibi "kaf" (ق) harfinin dammelenmesiyle [ötreli "u' sesiyle okunmasıyla] "hukuben" şeklinde okumuştur. "Kaf" harfi "hukben" şeklinde sâkin de okunmuştur. Böylece Aynı anlama gelen iki farklı kelime olmuştur. "Uzun uzun anlatma, abartma anlamına gelen "Itnab" (اطناب) kelimesinin kökü olan "ta-na-be" (طنب) (طنب) kelimesi de böyledir. Müsannifin, "hukuben ba'de hukubin" (بعد حقب ifadesi, "ahkâb" (احقابا) kelimesinin açıklamasıdır. Yine o, " bir hukub geçşe onu bir başka hukub takib eder ve sonsuza kadar böyle devam eder" şeklindeki açıklamasını bir başka cümlesiyle teyid eder: "elHukub ve el-hakabehu ifadesi ancak zamanların birbirini takip etmesini, birbirinin ardından gelmesini anlatır."86 "Hakabe") (حقب) kelimesinden türemiş olan "hakîbetü" (حقيبة) de müsannif tarafından teyid amaçı kullanılmışır. "Binicinin çantasını görmez misin? yani onun terkisindekini..." cümlesi de örneğidir.

\footnotetext{
80 Nebe 78/9.

${ }^{81}$ Atûfî, Hâşiyetü alâ Tefsîri'l-Keşşâf li Mevlânâ 'Atûfî 'alâ Cüzi'n-Nebei ilâ Âhirihî, , vr. 12a , ez-Zemahşerî, Tefsîru'lKeşşâf, 672.

${ }^{82}$ Atûfî, Hâşiyetü alâ Tefsîri'l-Keşşâf li Mevlânâ 'Atûfí 'alâ Cüzi'n-Nebei ilâ Âhirihî, vr. 11

${ }^{83}$ ez-Zemahşerî, Tefsîru'l-Keşşâf, s.672.

${ }^{84}$ Atûfî, Hâşiyetü ale'l-Keşşâf, Reisü'l-Küttâb , vr. 10a

${ }^{85}$ Atûfî, Hâşiyetü ale'I-Keşşâf bi Hatt-ı Müellifihi li'l-'Atûfî, vr. 17ª Zemahşerî, Keşşâf, IV, s. 675.

${ }^{86}$ Atûfî, Hâşiyetü ale'l-Keşşâf bi Hatt-ı Müellifihi li'l-'Atûfî, vr. $17^{\mathrm{a}}$
} 
Ayrıca, "el-hukub"un (الحقب), devenin karnından geçen kuşağın arka kısmını ifade ettiğini yine müsanniften nakletmiştir. ${ }^{87}$

Müellif, Ahkâb" (احقاب) kelimesinin ilâ nihâye [sonsuza kadar] devam eden bir sürece işaret ettiğini, kafirlerin bu durumda cehennemde ebedî kalacaklarına delâlet ettiğini söyler. Bu görüşü de hâşiyesinde en çok müracaatta bulunduğu müfessirlerden birisi olan Beydâvînin (ö.685-1286/87) görüşüyle destekler.

"Ahkâb" (احقاب), birbirini takip eden asırlardır. Bu ifadede oradan çıkışlarına dair bir delil yoktur. Şayet "hukub"un seksen ya da yetmiş bin yıl olduğu doğru olsa o zaman "ahkâb" sonsuzluk iktizâ etmez. Eğer mefhum yönünden bakılırsa mantûk ona zıt olmaz. ${ }^{88}$

Beydâvî'nin açıklamalarını benimseyen Nesefíden ise şu açıklamayı nakleder:

“Lâbisîne fîhâ ahkâben" (لبسين فيها احقابا), ifadesi orada çok uzun zaman kalanlar demektir. "Ve ahkâben" (و احقابا) ise, ilk harfi ötreli "hukub" (حقب) kelimesinin çoğuludur. 'Hâ' (ح) harfi kesralı olan "el-hıkbetü"

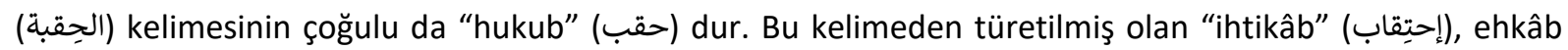
(احقاب) ise "erdâf" (الآرداف) anlamındadır. Ve bu kelime müterâdif, mütetâbi' zaman için bir isimdir. ${ }^{89}$

Halil b. Ahmed'in, (ö.170/786) “hukub" (حقب) takdiri mümkün olmayan dehr'den bir zamandır. Bu anlam muvâcehesinde 'lâbisîne fîhâ ahkâben' (لبسين فيها احقابا) ifadesi 'kesintisiz zaman' anlamı taşır. Bir 'hukub' (حقب) geçşe diğeri gelir, demek olur" ${ }^{\prime \prime 0}$ şeklindeki açıklamasını naklettikten sonra müellif, kendisi katılmasa da bu sürenin miktarıyla alakalı rivayetleri de nakleder.

İbn Mesûd, Ahkâb'ın sayısını Allah'tan başka kimse bilemez, bununla beraber bazı lügat ehli kimseler bu sürenin seksen sene olduğunu söylemiştir. Katâde de bu sürenin ahiretin seksen senesine karşılık geldiğini hatırlatmıştır. Yine Mücâhid, ahkâb'ın, kırk üç 'hukub' olduğunu, her hukub'un yetmiş 'bahar', her bahar'ın yedi yüz sene, her senenin 'üçyüz altmış gün', her günün de 'bin seneye karşılık geldiğini söyler. İbn Cüreyc de benzer bir şekilde, Muhammed b. Aclân'dan “hukub’un seksen küsür senedir, sene üç yüz altmış gündür, gün de bin senedir" ${ }^{91}$ dediğini nakleder.

Müellif, "ahkâb" kelimesinin anlamını toparlamak maksadıyla ebû İmâme'nin Hz. Peygamber'den naklettiğini söylediği, "hukb, bin aydır, her ay otuz gündür, böylece belirtilen süre seksen üç sene dört aydır. Fakat ahiretin her günü bin yıl gibidir"92 şeklinde rivayeti getirir.

Müellif, lügavî tahlil sürecinde sözcüklerin okunuşu hakkında bilgi vermiştir.

“Ke darbe'l-emîri" (كضرب الامير) ifadesinde "be" (بر) harfinin harekesinin "fetha" (بَ) olduğunu ve bu

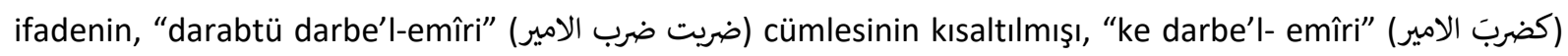
ifadesi olduğunu ifade eder. ${ }^{93}$

\footnotetext{
${ }^{87}$ Atûfî, Hâşiyetü ale'I-Keşşâf bi Hatt-ı Müellifihi li'l-'Atûfí, vr. $17^{a}$

${ }^{88}$ Atûfî, vr. $17^{\mathrm{b}}-18^{\mathrm{a}}$; el-Beydâvî, Envâru't-Tenzîl ve Esrâru't-Tevîl, thk. Muhammed Abdurrahman el-Mar'aşlı, V, s. 280.

${ }^{89}$ Atûfî, Hâşiyetü ale'I-Keşşâf bi Hatt-ı Müellifihi li'I'‘Atûfí, vr. 18'; Halil b. Ahmed, Kitâbü'I-Ayn, III, s.53.

${ }^{90}$ Atûfi, Hâşiyetü ale'I-Keşş̧âf bi Hatt-ı Müellifihi li'l'-Atûfi, vr. $18^{\mathrm{b}}$

${ }^{91}$ Atûfî, Hâşsiyetü ale'I-Keşşâf bi Hatt-ı Müellifihi li'l-'Atûfí, vr. $18^{a}$

${ }^{92}$ Atûfî, Hâşiyetü ale'l-Keşşâf bi Hatt-ı Müellifihi li'l-'Atûfí, vr. $18^{a-b}$

${ }^{93}$ Atûfî, Hâşiyetü ale'I-Keşş̂́f bi Hatt-ı Müellifihi li'I-'Atûfî, vr.9a', Ebu Abdirrahman Abdullah ibn Mübârek, ez-Zühd ve'r-Rekâik li ibni'I-Mübârek, I, s.90; Bu rivayet Zevâid ve Tahric kitaplarında geçmektedir. Münker hadis olarak kabul edilmiştir. Çünkü râvîlerinden Kasım ve Ca'fer b. Zübeyr metrûktür. Bkz. el-Bûsayrî el-Kinâî eş-Şâfiî, Ebu'IAbbas Şihâbü'd-Din Ahmed, ithâfü'l-Hiyerati'l-Meherati bi Zevâid-i Mesânîdi'l-Aşerati, thk. Ebû Temîm Yâsir b. ỉbrâhîm, VI, s. 298; ỉbn Hacer el-Askalânî, el-Metâlibü'I-Âliye bi Zevâid-i Mesânîdi's-Semâniye, XV, s. 423, Ebû Abdurrahman Mahmûd b. Muhammed el-Mellâh, el-Ehâdîsu'd-Daîfeti ve'I-Mevdûati elletî Hakeme Aleyhâ Hafız ibn Kesîr fi Tefsîrihî, s. 410.
} 
Bir başka örnek olarak, "Sübâten (سُباتا), bazı hastalık isimleri kalıbında gelir" şeklindeki müsannifin cümlesini

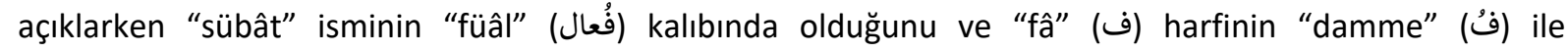
okunduğunu söyler. "Düvâr"(دوار), Hünâk (حناق), Süâl (سعال), Kuyâ (جياء), Cüzzâm (جزام) gibi bazı hastalık isimlerini de örnek gösterir. ${ }^{94}$

"Mu'sırât" (معصرات) kelimesinin açıklamasında da benzer bir yöntem izlendiğini görmekteyiz. Müsannifin "zevâte'l-eâsîr" (ذوات الأعاصير) ifadesini,,95 “el-eâsîr" (الأعاصير), "i'sâr" (إعصار) kelimesinin çoğuludur, "kesralı hemze" (إعصار) ile okunur. O, yeryüzünde esen rüzgardır. Toplu, yoğun ve yükseklerden yeryüzüne doğru eser ve karşılaştığı toz, ot, elbise türü şeyleri yukarı doğru kaldııı ${ }^{96}$ şeklinde açıklamıştır.

Müellif, bazen de ayette geçen, fakat müsannif tarafından açıklanmamış garîb kelimelerle ilgili kısa açıklayıcı bilgiler vermiştir.

Müsannif “elfâfen” (الفافا) lafzını açıklarken bu kelimenin “evzâ'” (اوزاعibi olduğunu söylemiştir. Müellif de örnek gösterilen kelimeyi açıklayıp müsannifin açıklamalarının daha anlaşılır olmasına katkı sağlamıştır. Müellifin katkısı şöyledir:

"El-evzâ"” insanlardan oluşan toplulukların ismidir. Lafzın tekil formu yoktur. Ancak "cemâât" (جماعات), lafzının tekili vardır ve "cemâatün"dür (جماعة). ${ }^{97}$

Müsannifin "elfâfen" kelimesini açıklamak için kullandığı diğer kelime "ehyâf" (اخياف) tır. Bu kelime de müellif tarafından açıklanmıştır:

“Ehyâf" (اخياف), mühtelifât demektir. Yani farklı türden olanlar anlamına gelir. Bu kelime "ihvetün ehyâfün" (إخوة اخياف), şeklinde anneleri bir babaları farklı olan kardeşler için kullanılır ${ }^{98}$ demiştir.

Müsannif, "el-kevâkib" (الكواعب) kelimesini "memesi yuvarlak olanlardır." Nevâhid (نواهج), "etrâb")(تراب) ve "ellidât"(اللدات) bunlardır"9 şeklinde tefsirini yaptıktan sonra müellif, müsannifin açıklamak niyetiyle kullandığı "nevâhid, etrâb ve el-lidât" kelimelerini de şerh etme gereği hisseder ve şöyle açıklar:

"Nevâhid", nâhid kelimesinin çoğuludur ve memesi yuvarlak olan kimsedir. 100 "Ellidât", lâm harfinin kesralı okunuşu ile, "lidetün" kelimesinin çoğuludur. Mânâsı Türkçe doğdaşlar, yani bir zamanda doğanlar demektir. ${ }^{101}$ Etrâb kelimesine gelince onlar bir yaştaki şahıslardır. Aynı zamanda veya yakın zamanlarda doğmuş kişilere denir. ${ }^{102}$

\subsubsection{Belâgatla İlgili Açıklamaları}

Müellifin belâgata yönelik açıklamaları, meânî ve beyân türündendir. Lügavî açıklamalarında görüldüğü gibi belâgat ile ilgili açıklamaların da da müsannifin eksik bıraktığını tamamlayıcı, kapalı ifadelerini açıklayıcı, cümlenin mahiyetini tesbite yönelik niteliktedir. Özellikle Nebe süresi bağlamında yaptığımız incelemelerde

\footnotetext{
${ }^{94}$ Atûfî, Hâşsiyetü ale'I-Keşşâf bi Hatt-ı Müellifihi li'I-'Atûfî, vr. 10

${ }^{95}$ Ez-Zemahşerî, el-Keşşâf, IV, s. 672; Atûfî, vr. 14 ${ }^{\mathrm{b}}$

${ }^{96}$ Atûfî, Hâşiyetü ale'I-Keşşâf bi Hatt-ı Müellifihi li'l-'Atûfí, vr. $14^{\mathrm{b}}$

${ }^{97}$ Atûfí, Hâşiyetü ale'l-Keşşâf bi Hatt-ı Müellifihi li'l-'Atûfí, vr. $15^{\mathrm{b}}$

${ }^{98}$ Atûfí, Hâşiyetü ale'l-Keşşâf bi Hatt-ı Müellifihi li'l-'Atûfí, vr. 15

${ }^{99}$ Ez-Zemahşerî, el-Keşşâf, IV, s. 690.

${ }^{100}$ Atûfî, Hâşiyetü ale'I-Keşşâf bi Hatt-ı Müellifihi li'l-'Atûfî, vr. 21ª

101 Türk dil Kurumu, Tarama Sözlügü,

http://www.tdk.gov.tr/index.php?option=com_tarama\&arama=kelime\&guid=TDK.GTS.5ac253c229ea07.48271

326, Atûfî, Hâşiyetü ale'I-Keşşâf bi Hatt-ı Müellifihi li'I-'Atûfi vr. 21 ${ }^{\text {a }}$

${ }^{102}$ Atûfî, Hâşiyetü ale'I-Keşşâf bi Hatt-ı Müellifihi li'l-'Atûfî vr. 21
} 
beyân konularından mecâz, ${ }^{103}$ istiâre, ${ }^{104}$ kıyas, ${ }^{105}$ cümleler arasında mülâzemet ilişkisi, ${ }^{106}$ istisnâ, ${ }^{107}$ mübâlağa, ${ }^{108}$ iltifat ${ }^{109} \mathrm{vb}$. kurallara değindiği görülmüştür.

\subsubsection{Ulûmu'I-Kur'ân ve Diğer Disiplinlere Dâir Açıklamaları}

Müellif, sürelerin Mekkî-Medenî oluşuna kısaca değinmiştir. ${ }^{110}$ Nebe sûresinin başında "Amme sûresi Mekkî'dir, Nebe sûresi olarak isimlendirilir" ${ }^{111}$ şeklinde bilgi vermiştir. Mekkî ya da Medenî oluşu hakkında kesin bilgi sahibi olmadığı durumlarda "o konuda ihtilaf edilmiştir"112 demiştir.

Kıraat konusundaki açıklamaları daha ziyade kelimelerin okunuşları ile ilgilidir. Kıraat ile ilgili nakillerini genellikle Ebû Hafs Necmüddin Ömer en-Nesefî (537/1142)'nin Teysîr'inden yapmış, ayrıca kıraat âlimlerin görüşlerine de yer vermiştir. ${ }^{113}$ ibn Kesîr (120/738), Kisâî (ö. 189/805), Ebû Amr (ö.444/1052) görüşlerine müracaatta bulunduğu âlimlerdir. ${ }^{114}$

Dil ve belâgat ile ilgili alıntıları, “Ferrâ (ö.207/822), Ma’mer b. el-Müsennâ (ö.209/824), Kutrub (ö.206/821), İbn Kuteybe (ö.276/889)"115 gibi âlimlerden isimlerini zikrederek yapmıştır. Hadis nakilleri de genellikle “ibn Mesûd, Katâde, Mücahid, ibn Cüreyc, ibn Abbas" ${ }^{116}$ gibi râvîlerdendir.

Müsannifin mezhebî görüşlerine imkân nisbetinde değinmeyen müellif, bazı mutezîî görüşleri eleştirmekten çekinmemiştir. Nebe sûresi haricinde bunun örneklerini görmek mümkündür. ${ }^{117}$ Ayrıca bazı inkârcı fırkaların mahiyeti hakkında bilgi vermiştir. ${ }^{118}$

Müellif, tasavvufî açıklamalar da yapmıştır. Yine Nebe süresi haricinde görülen örneklerden bir tanesi nefsin mahiyeti hakkındadır. ${ }^{119}$

Ayetlerin imkân verdiği durumlarda insan bedeni ile ilgili biyolojik açıklamalarda bulunmuştur. "Sulb ve terâib" hakkındaki açıklamaları bu türdendir. ${ }^{120}$

\section{Kaynakları}

Bazen kitap ismiyle, bazen müellifine işaret ederek, zaman zaman da ikisini zikrederek kaynaklardan alıntı yaptığı görülen müellif, en çok Ömer en-Nesefî'nin et-Teysîr'inden istifade etmiştir. ${ }^{121}$ Fahru'd-Dîn er-Râzî

\footnotetext{
${ }^{103}$ Atûfî, Hâşiyetü ale'l-Keşşâf bi Hatt-ı Müellifihi li'l-'Atûfî vr. $5^{a}$

${ }^{104}$ Atûfî, Hâşiyetü ale'l-Keşşâf bi Hatt-ı Müellifihi li'l-'Atûfî vr. $7^{\text {b }}$

${ }^{105}$ Atûfî, Hâşiyetü ale'l-Keşşâf bi Hatt-ı Müellifihi li'l-'Atûfí vr. $7^{\text {b }}$

${ }^{106}$ Atûfî, Hâşiyetü ale'l-Keşşâf bi Hatt-ı Müellifihi li'l-'Atûfî vr. $8^{\text {b }}$

107 Atûfî, Hâşiyetü ale'l-Keşşâf bi Hatt-ı Müellifihi li'l-'Atûfî vr. 19

${ }^{108}$ Atûfî, Hâşiyetü ale'l-Keşşâf bi Hatt-ı Müellifihi li'I-'Atûfî vr. 20a

${ }^{109}$ Atûfî, Hâşiyetü ale'l-Keşşâf bi Hatt-ı Müellifihi li'l-'Atûfî vr.21 ${ }^{\text {b }}$

${ }^{110}$ Atûfî, Hâşiyetü ale'I-Keşşâf bi Hatt-ı Müellifihi li'l-'Atûfî, vr. 37ª $61^{\mathrm{a}}$, $75^{\mathrm{a}}$

${ }^{111}$ Atûfî, Hâş̧iyetü ale'l-Keşşâf bi Hatt-ı Müellifihi li'l-'Atûfî, vr. $3^{\text {a }}$

${ }^{112}$ Atûfî, Hâşiyetü ale'I-Keşşâf bi Hatt-ı Müellifihi li'l-'Atûfí, vr. 133'

${ }^{113}$ Atûfî, Hâşiyetü ale'l-Keşşâf bi Hatt-ı Müellifihi li'l-'Atûfî, vr. 59'

${ }^{114}$ Atûfî, Hâşiyetü ale'l-Keşşâf bi Hatt-ı Müellifihi li'l-'Atûfî, vr. 59'

115 Atûfî, vr. 23 ${ }^{\mathrm{b}}$

${ }^{116}$ Atûfî, Hâşiyetü alâ Tefsîri'l-Keşşâf li Mevlânâ 'Atûfî 'alâ Cüzi'n-Nebei ilâ Âhirihî, vr. 22

117 Örnekler için bkz. Atûfî, Hâşiyetü ale'l-Keşşâf bi Hatt-ı Müellifihi li'l-'Atûfî, vr. 60ª $86^{\mathrm{a}}, 87^{\mathrm{a}}, 93^{\mathrm{a}}$,

${ }^{118}$ Atûfî, Hâşiyetü ale'l-Keşşâf bi Hatt-ı Müellifihi li'l-'Atûfî, vr.7ª

${ }^{119}$ Atûfî, Hâşiyetü ale'l-Keşşâf bi Hatt-ı Müellifihi li'l-'Atûfî, vr. 100ª $101^{\text {a-b }}$

${ }^{120}$ Bkz. Atûfî, Hâşiyetü ale'l-Keşşâf bi Hatt-ı Müellifihi li'l-'Atûfî, vr. $82^{\mathrm{b}}-84^{\mathrm{b}}$

${ }^{121}$ Atûfî, Hâşiyetü ale'l-Keşşâf bi Hatt-ı Müellifihi li'l-'Atûfî, vr. 28ª , 58ª , 59
} 
(ö.606/1210)'nin Tefsîr-i Kebîr'inden, ${ }^{122}$ Beydâvî (ö.691/1292)'nin Meâlimü't-Tenzîl'inden, ${ }^{123}$ Tacuddîn Ahmed el-Cendî (ö.700/1301)'nin Zemahşerînnin Mufassal isimli eserine yaptığı şerh olan elİklîd'den ${ }^{124}$ nakillerde bulunmuş ayrıca bazı müfessirler ${ }^{125}$ diyerek kaynak vermeden görüşler nakletmiştir.

Lügavî açıklamalarında, Cevherî́nin (ö.400/1009) es-Sıhah'ından, ${ }^{126}$ Mutarrizî́nin (ö.610/1213) elMu'rib'inden ${ }^{127}$ ve Ferrâ'nın (ö.207/822) görüşlerinden ${ }^{128}$ istifade etmiştir.

Fıkhî konularda ise Hidâye sahibi Mergınânî'den (ö.593/1196), ${ }^{129}$ Ebû Hanîfe (ö.150/767) ve Malik'in (ö.179/795) görüşlerinden ${ }^{130}$ kaynak belirtmeden faydalanmıştır.

\section{Vaaz ve İrşad Nitelikli Açıklamaları}

Müellifin haşiyesinde iki yönün bariz olarak öne çıktı̆̆ı söylenebilir. Birincisi, Dil ve Belâgata dair açıklamalar, diğeri ise îtikâdî meseleleri açıklamaya yönelik vaaz ve irşad nitelikli tesbitlerdir. Bu bölümde ikinci husus ele alınacak örneklerle açıklanacaktır.

Müellif, konuyu tartışırken muhatap kitlenin anlayacağı bir dil kullanmaya çalışmış, Kelâm ilminin tartışmaya müsaid olan konularını basit örneklerle, anlaşılır bir dille açıklamıştır. Meselâ öldükten sonra dirilme (ba's) konusunda kafirlerin iki fırka olduklarını, birinci fırkanın, en büyüğünden en küçüğüne kadar kaderin içinde yer alan bütün işleri yaratan kâmil kudreti inkar edenler olduğunu söyler. Bu kimseler ayetin ifadesiyle“...Bu çürümüş toz haline gelmiş kemikleri kim yaratacak?" 131, "Çürümüş kemikler olduğumuz zaman mı?"132 diyenlerdir. i̇kinci fırka da inanan ve kâmil kudreti kabul edenler oldukları halde kendilerinin diriltileceklerine inanamayanlardır. Bu kimseler ayetlerin tarifiyle: "Kendilerine sorsanız, semâvâtı ve arzı kim yarattı? Allah derler." 133 "De ki: "Sizi gökten ve yerden kim rızıklandırıyor? Ya da işitme ve görme yetisi üzerinde kim mutlak hakimdir? Ölüden diriyi, diriden ölüyü kim çıkarır? İşleri kim yürütüyor? 'Allah' diyecekler." 134 "Fakat onlar Allah'ın ölüyü dirilteceğine yine şöyle diyenleri dirilteceğine..." inanmıyorlar. Biz gerçekten gerisin geriye eski halimize mi döndürüleceğiz?"135 diyenlerdir.

Bu kimseler genel anlamda Allah'ın yaratıcı ve rızık verici olduğunu kabul etmekle birlikte kendilerinin tekrar diriltileceklerine inanmamaktalar. Müellif, onların bu durumunu çocuk metaforuyla açıklar. Sanki onlar bu âlemin yaratılması, Allah Teâlâ'nın şe'ni hakkında bir çocuk gibi konuşurlar. O çocuk sabahtan akşama kadar bir dairecik bina eder, akşam olunca da hiç kimse ondan istifade etmesin diye eliyle onu yıkar. O kimse gerçekten boş işle uğraşan bir oyuncudur. Halbuki Allah Teâlâ zalimlerin söylediklerinden çok yüce ve en büyük olandır.

Müellife göre bu iki fırkanın iddiaları Kur’an-ı Kerim tarafından cevaplandırılmıştır.

\footnotetext{
${ }^{122}$ Atûfî, Hâşiyetü ale'l-Keşşâf bi Hatt-ı Müellifihi li'l-'Atûfî, vr.60

${ }^{123}$ Atûfî, Hâşiyetü ale'l-Keşşâf bi Hatt-ı Müellifihi li'l-'Atûfî, vr. 68

${ }^{124}$ Atûfî, Hâşiyetü ale'l-Keşşâf bi Hatt-ı Müellifihi li'l-'Atûfî, vr. 15'

${ }^{125}$ Atûfî, Hâşiyetü ale'l-Keşşâf bi Hatt-ı Müellifihi li'l-'Atûfî, vr.76

${ }^{126}$ Atûfî, Hâşiyetü ale'l-Keşşâf bi Hatt-ı Müellifihi li'l-'Atûfí, vr. 27b $80^{\mathrm{a}}$

${ }^{127}$ Atûfî, Hâşiyetü ale'l-Keşşâf bi Hatt-ı Müellifihi li'l-'Atûfî, vr. 28a

${ }^{128}$ Atûfî, Hâşiyetü ale'l-Keşşâf bi Hatt-ı Müellifihi li'l-'Atûfî, vr.80'

${ }^{129}$ Atûfî, Hâşiyetü ale'l-Keşşâf bi Hatt-ı Müellifihi li'l-'Atûfî, vr. $65^{\text {a }}$

${ }^{130}$ Atûfî, Hâşiyetü ale'I-Keşşâf bi Hatt-ı Müellifihi li'l-'Atûfî, vr. 74-75'

131 Yasin 36/78.

132 En-Nâziat 79/11.

133 Lokman 31/25.

134 Yunus 10/31.

135 En-Nâziat 79/10.
} 
Meselâ, "Biz, yeryüzünü bir döşek yapmadık mı?”"136 şeklindeki aklî delillere götüren ve mahlukattan alınmış uyarıcı ayetler, ba'sı, yakînî ilim olarak açıklayan, faydalı neticeler veren ayetlerdir. ${ }^{137}$ Hâsılı bu uyarıcı ayetlerden elde edilen delil birinci fırka için bir hüccettir. Şöyle ki: Allah, semâvâtı, arzı ve içindekileri yaratmaya kadirse ba's ve ölüyü diriltmeye de kadirdir. ${ }^{138}$ Müellif, bu meseleyi basit bir mantık örgüsü içinde anlatmayı da dener. Allah Teâlâ'nın semâvât ve arzı yaratmaya güç yetirmesi, istisnaî kıyas yoluyla ba'sa da kâdir olduğunun delilidir. Bu aynı zamanda mülâzemet ilişkisinin ifadesidir. Çünkü, kâinâtı yaratmaya kâdir olan ondan daha basit olan ölüyü diriltme ve ba'sı gerçekleştirmeye tabii ki kâdirdir. ${ }^{139}$

İkinci fırkanın iddialarına cevap olarak onlara şöyle söylenmesi gereklidir: "Allah Teâlâ bu çok ve hikmetli işlerin fâili olduğunda yaptıklarının karşılığı olarak mevtayı diriltmesi de gerekir. Lâkin lâzım ve melzûm sabit olmalıdır. Allah Teâlâ’nın cezâ (amellerin karşıı̆ı)) için ölüyü diriltmesi yine mülâzemet ilişkisinin gereğidir. Çünkü bütün işlerinde mahzâ hikmetle iş yapan Allah, ölüyü ceza yurdunda diriltmezse imtihan dünyasında yaptığı bütün işler abesle iştigal olur. O zaman lâzım batıl, melzûm da batıl olur." ${ }^{140}$

Müellif, bazen müsannifin özet geçtiği noktalardaki Kudret-i Illahiye'ye işaret eden hikmetleri zikretmeyi kendisi için bir borç bilmiş ve hakîkatin, müsannifin işaret ettiği zâhirî bazı açıklamalarla sınırlı olmadığını vurgulamak istemiştir. Meselâ "وَجَعَلْنَا اللَّيْلَ لِبَاسًا" (Nebe 78/10) ayetinde gece-gündüz arasındaki ilişki bir benzetmeyle anlatılmış, elbise nasıl insan bedenini korursa gece de öyle bütün mevcûdâtı korur denmiştir. Müsannif, bu ayetin tefsîri olarak sadece gece ile elbise arasında teşbih sanatının olduğunu söylemiş, hikmet olarak da "sizi muttalî olmak istemediğiniz kimselerin bakışlarından korur" ${ }^{141}$ yorumuyla yetinmiştir. Halbuki müellife göre bu ifadede kudret-i tâm'a ve nîmet-i tâm'a işaretler vardır. Bu işaretler de şöyledir:

Gece, insanlığın, hayvanatın, bitkiler âleminin, madenlerin kemâlatı için bir sebeptir. Çünkü gece, gündüzün yakıcı hararetinden gelecek zararı önler. Bu üç önemli alemin fertlerinin aslî cüzlerine girmesini engeller. Bu sayede mizaçlarına uygun olarak kemâliyle büyürler ve güçlenirler. ${ }^{142}$ Ayrıca, gecenin faydalı rutubete sahib olması, yıldızların nurlarından hüzmelerin ortaya çıkması, gündüzün kederli havası, yerini geceleyin temiz ve dinlendirici bir havaya bırakması, sıcaklığın ve soğukluğun vereceği zararı defetmesi ${ }^{143}$ gecenin faydalarından bazılarıdır.

Müellif, konunun hatırına getirdiği şeyleri irşâd niyetiyle paylaşmıştır. "Uykunuzu sizin için istirahat (sebebi) kıldık" ${ }^{144}$ ayetinden hasıl olan mânâyı toparlarken aklına gelen ve uykunun nimet oluşunu ifade eden açıklamalar da bu niteliktedir. ${ }^{145}$

Müellif zaman zaman tetimmeler hazırlayarak düşüncelerini açıklamıştır. Bu tetimmelerin kendisinden önce bir şekilde kaleme alınmadığını umarak kaleme alındığını ve bu vesile ile kendisi için dua talep ettiğini şu cümleleriyle ifade etmiştir. "Zaman ehlinden bir kişi eliyle benden önce kaleme alınmadığını umarak bu araştırma ve yazıyı hazırladım. Bağışlanmam için dua rica ediyorum." ${ }^{146}$

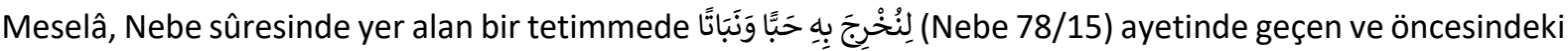
"su" (ماء)" kelimesine dönen "ba-i sebebiyye"nin (به) hikmeti sorgulanmıştır. Yani Allah Teâlâ, Tekvin sıfatıyla

\footnotetext{
${ }^{136}$ En-Nebe 78/6.

${ }^{137}$ Atûfí, Hâşiyetü alâ Tefsîri'l-Keşşâf li Mevlânâ 'Atûfí 'alâ Cüzi'n-Nebei ilâ Âhirihî, vr. $8^{b}$

${ }^{138}$ Atûfî, Hâşiyetü alâ Tefsîri'l-Keşşâf li Mevlânâ 'Atûfí 'alâ Cüzi'n-Nebei ilâ Âhirihî, vr. $8^{\text {b }}$

${ }^{139}$ Atûfî, Hâşiyetü alâ Tefsîri'l-Keşşâf li Mevlânâ 'Atûfí 'alâa Cüzi'n-Nebei ilâ Âhirihî, vr. $9^{a}$

${ }^{140}$ Atûfî, Hâşiyetü alâ Tefsîri'I-Keşşâf li Mevlânâ 'Atûfí 'alâ Cüzi'n-Nebei ilâ Âhirihî, vr. $10^{\text {b }}$

${ }^{141}$ ez-Zemahşerî, Tefsîru'I-Keşşaff, 672.

${ }^{142}$ Atûfî, Hâşiyetü alâ Tefsîri'l-Keşşâf li Mevlânâ 'Atûfí 'alâ Cüzi'n-Nebei ilâ Âhirihî, vr. 15

${ }^{143}$ Atûfî, Hâşiyetü alâ Tefsîri'l-Keşşâf li Mevlânâ 'Atûfî 'alâ Cüzi'n-Nebei ilâ Âhirihî, vr. 15

${ }^{144}$ En-Nebe 10/9.

${ }^{145}$ Bkz.Atûfí, Hâşsiyetü ale'l-Keşşâf, vr. $10^{\mathrm{b}}-12^{\mathrm{b}}$

${ }^{146}$ Atûfî, Hâşiyetü alâ Tefsîri'l-Keşşâf li Mevlânâ 'Atûfí 'alâ Cüzi'n-Nebei ilâ Âhirihî, vr. 20a
} 
sebepsiz yaratabilme gücüne sahipken neden yaratması için sebep bildirilmiştir? ${ }^{147}$ Bu sorunun cevabını da müellif şöyle vermiştir: Bu örnekteki sebebiyyet, âdî sebebiyettir. Âdî sebep de Allah Teâlâ'nın katında müsebbebini âdetin cereyanı yoluyla yarattığı sebeptir. Adet ise çoğunlukla dâimî olarak tekrar eden fiillerdir. Yine "varlık âleminin çoğunda âdetin cereyan etmesinin hikmeti nedir? Niçin varlıklar Allah'ın irâdesine ittifak halinde tâbîdir?" şeklinde sorulabilecek sorulara kendisi şöyle cevap verebileceğini ifade etmiştir: "Semâvâtın ve iki arzın yaratılmasındaki maslahat, ilim ve onunla amel şeklindeki iki cevherin elde edilmesidir. İlim ve onunla amel, nübüvvetin subûtu ile uyum içindedir. Nübüvvetin sübûtu Nebî'nin duasıyla âdet-üstülükle [hâriku'l-âdelikle] uyumludur. Âdet-üstülük de âdetin cereyanından sonra olur. Âdetin cereyanı büyük bir hikmet ve maslahat içerir. Âdetin cereyanı üzere mahlukatın yaratılması ise imtihan içindir. Onun sebeplerini ancak yaratana doğru yönelen kimse bilir. ${ }^{148}$

\section{Sonuç}

Hayreddin Hızır el-Atûfî, II. Bayezîd, Yavuz Sultan Selim ve Kânûnî Sultan Süleyman dönemlerinde yaşamış, II. Bâyezid'in özel iltifatına mazhar olarak saray muallimliği yapmış, saray kütüphanesinin hafız-ı kütübü olmuş, İstanbul'un salâtin camilerinde vaizlik ve tefsir mukarrirliği yapmış bir Osmanlı alimidir. Merzifonlu'dur. Bugün bile çocuklarının isimlerinden ismini almış köyler bulunmaktadır. Atûfínin Merzifonlu oluşunun bir başka göstergesi kullandığı mahlasıdır. Bazı risalelerinde Merzifônî mahlasını kullanmıştır. Atûfínin hayatında yeri olan bir başka şehir de Kastamonu'dur. Kastamonî mahlasını kullanmış ve bazı tabakat kitapları da bu mahlas ile ondan bahsetmiştir. Hayatının önemli bir bölümünü İstanbul'da geçiren müellif, son zamanlarını ilmî teliflere hasretmiş, dînî ve aklî ilimlere dair döneminin meşhur bazı eserlerine şerhler ve hâşiyeler yazmış, 1541 yılında İstanbul'da vefat ettiğinde geride on küsur adet, şerh, hâşiye ve de müstakil eser bırakmıştır.

İnceleme fırsatını bulduğumuz Keş̧̧âf hâşiyesini Atûfî, namazlarda en çok okunan amme cüzü üzerine hazırlamış, özellikle anlaşılmasında güçlük bulunan bölümlerinin şerhini yapmayı amaçlamıştır. Netice itibariyle bu düşüncesine sadık kaldığı da görülmüştür, zîra müellif, sadece gerekli gördüğü yerlerde esas metne müdahil olmuştur. Bu yönüyle haşiyesi müstakil tefsir çalışması gibi de değildir. Müellifin tefsir müktesebâtı hakkında bir fikir verse de onu tam olarak ortaya koyabileceği düşüncesinde değiliz. Bu farklıık müstakil bir tefsir risalesi olan Hısnü'l-âyati'l-ı'zâm fî tefsir-i evâil-i süreti'l-en'âm risalesinde görülebilmektedir. Aynı şekilde Fesuhkan li ashabi's-seîr risalesi de haşiye olmakla birlikte, müfessirin konuyla ilgili birikimini görebilme imkânı sunabilmektedir.

Atûfî'nin Keşşâf hâşiyesini iki yüz küsür varaklık hacmiyle (toplamda 400 küsür sayfa) inceleyip bir tebliğ ebatlarında sunmaya çalışmak tebliğ sınırlarının üstünde olduğu için çalışmamızda bu hâşiyenin ilk sûresi olan Nebe sûresi hâşiyesini ( 28 vr.=56 sayfa) inceleyip, genel özellikleri ve tefsir yöntemiyle ilgili tesbitlerde bulunmaya gayret ettik.

Bu çerçevede hâşiyenin Türkiye kütüphaneleri veri tabanına kayıtlı 9 adet nüshası bulunduğunu, her bir nüshada farklı isimlendirildiğini gördük. Bunun çeşitli sebepleri olmakla beraber, müstensihlerin kitap üzerine düştükleri başık nevinden notların, kataloglama esnasında yapılan hataların bu farklılığın sebepleri olarak görülebilir.

Bu nüshalardan Süleymaniye Kütüphanesi bünyesindeki, Reisu'I-Küttâb, nr. 927, Yeni Câmî, nr.144/1, Şehid Ali Paşa, nr.263'teki nüshaları incelememiz esnasında kullandık.

Yeni Câmî nüshasında hâşiyenin bitiminden sonra akrostiş tarzında on dört beyitten oluşan Sultan Süleyman Hana ithafen yazıımış bir şiir vardır. Şiir Necâtü'l-Akabat isimli bir risalenin başında yer alır. Hâşiyenin

\footnotetext{
${ }^{147}$ Atûfî, Hâşiyetü alâ Tefsîri'l-Keşşâf li Mevlânâ 'Atûfí 'alâ Cüzi'n-Nebei ilâ Âhirihî, vr. 19'-20a

${ }^{148}$ Atûfî, Hâşiyetü alâ Tefsîri'l-Keşşâf li Mevlânâ 'Atûfí 'alâ Cüzi'n-Nebei ilâ Âhirihî, vr. 19º $20^{\mathrm{a}}$
} 
sonundaki ferağ kaydında ise müellif tarafından telif tarihini belirten bir bilgi bulunur. [Fakir ve hakir kul Âtûfi, 927 senesi muharrem ayında Perşembe günü duhâ vaktinde Allah'ın lütfuyla te'lifini tamamladı]

Hâşiyenin metoduna yönelik yaptığımız analizler neticesinde şu hususların öne çıktı̆̆ını söyleyebiliriz:

Müellif, sahip olduğu ilmî birikimini içinde yaşadığı toplumun ihtiyaçları uğruna tüketmeyi kendisi için görev addetmiş bir halk adamıdır. Yaptığı şerh ve haşiyelerin birçoğunda hedef kitlesi halkıdır. Keşşaf hâşiyesi olarak hazırladığı eseri de Müslüman halkın en çok ihtiyaç duyduğu bir alana yönelik olmuştur. Ancak müellifin yaptığı açıklamaların mahiyetine, açıklanan kısımların niteliğine bakıldığında açıklamaları anlayacak kadar dil ve belagat bilgisine sahip bir kitlenin muhatap alındığı anlaşılacaktır. Baas, haşr, kıyamet, tekrar yaratılma, Allah'ın güç ve kudreti, irâde-i külliye ve cüziyye vb. konularda yaptığı açıklamalarla da Kelâm ilminin bu türlü tartışmalı konularından haberdar olan bir kesime hitap edildiği anlaşılmaktadır. Kaynakların verdiği bilgilerden de istifade ederek şöyle bir tesbitte bulunmak bu aşamada mümkündür. Atufínnin Keş̧̧af haşiyesi camilerde Keşşaf tefsiri takrirleri esnasında oluşmuştur. Neden tamamı değil de sadece en-Nebe ve sonrası olduğunu ise kendisi açıklamıştır. Niçin başka bir tefsir değil de Keşşâf tefsiri diye sorulursa, o takdirde de medreselerde en çok okutulan tefsir olması, bu tefsir ile ilgili zihninde toparladığı sorun anlamında tesbitler olması, bunları medrese ehli talebelerle paylaşmak istemesi Keş̧âf'ın takrir edilmesinde etkili olmuş olabilir. Meselâ ba's ve diriliş konusundaki katkıları bu açıdan değerlendirilebilir. Musannifin Kudret-i illahiyyeye işaret eden hikmetleri zikretmedeki açıklamalarının yetersiz bulunduğu noktalarda hakikatin, müsannifin ibarelerin zahirinden çıkardıklarıyla ile sınırlı olmadığını vurgulaması da düşüncemizi desteklemektedir. Bu bağlamda konunun hatırına getirdiği şeyleri de paylaşmaktan geri durmamıştır. Fakat müsannifin itizâlî fikirlerine imkân nisbetinde girmemiştir.

Önemli gördüğü ve sonradan ilave ettiği düşüncelerini tetimme başlığiyla haşiyesine eklemiştir. Bu tetimmelerin kendisinden önce bir şekilde kaleme alınmadığını umarak yazdığını belirtmiş, kendisi için dua edilmesini de talep etmiştir.

Müellifin hâşiyesinde tebârüz eden diğer bir yön ise, rivayet ve dirayet tefsir usullerini kullanmış olmasıdır. Bu hususta şunların altı çizilebilir:

Rivayet ve dirayet tefsir yöntemlerinden her ikisine dair örnekleri görebildiğimiz hâşiyenin dil-belagat ve vaaz- irşad ağırlıklı bir açıklama stratejisiyle hazırlandığı söylenebilir. Edatların mahiyeti ve cümleye kattığı anlam, cümle ve sözcük tahlilleri, beyânın unsurlarından edebi sanatlara işaretler, Mekkî-Medenî, Esbâb-ı Nüzûl ve Kıraat konularına giren müellif, irşâdî açıklamaları esnasında ise Fıkıh, Kelam, Tasavvuf ve tabii bilimler gibi disiplinlerin ilgi alanlarına giren bilgiler verdiği görülmüştür. Dil ile ilgili açıklamalarını Halil b. Ahmed, İbn Cüreyc, Ferrâ, Ma'mer, Kutrub gibi dil bilginlerinin rivayetlerine dayandırırken Kıraat konusunda ise Kisâî, İbn Kesir ve Ebû Amr'ın görüşlerinden faydalanmıştır. Farklı fırkaların Kur'an'a ters yaklaşımlarını yine Kur'an bütünlüğünde delillerle cevaplamıştır. Bu esnada Kur'an ve hadîsi referans olarak kullanmıştır. Hadisler Hasan el-Basrî, ibn Mesûd, Katâde, Mücahid'den oluşan hadis ehlinin rivayetlerini nakletmiştir.

Yorumlarını tefsir kaynaklarından istifade ile müdellel hale getirmiş, Ömer en-Nesefínnin Teysîr'inden ve Beydâvî'nin Envâru't-Tenzîl'inden sık sık alıntılar yapmıştır.

Müellifin yaptığı çalışmadan çıkan sonuçları eserin kıymet-i ilmiyyesi zaviyesinden değerlendirdiğimizde ise hedef kitlesi ve sorunsalı belirli bir çalışma yapması yönüyle orjinal ve değerlidir. Zira tefsir çalışmalarının veya ilahiyat alanıyla ilgili disiplinlerde yapılan çalışmaların birçoğunun toplumun ilgi ve ihtiyaçlarından uzak arkeik nitelikli çalışmalar olduğundan yakınılır. Ayrıca her tarihî eser gibi sosyolojik açıdan incelendiğinde dönemin din sosyolojisi, toplumun ilgi ve ihtiyaçları, sorunları hakkında bilgi edinmeye müsait olması yönünden de önem arz ettiği düşünülebilir.

Hâşiye, üslûb ve yöntem olarak ilmî bir hüviyete sahiptir. Müellif, çalışmasında iki şeye odaklanmıştır. Bunlardan birisi cümlelerin zahiren neyi ifade ettiği diğeri de cümlelerin neyi kastettiğidir. Birinci kısımda 
lügavî, nahvî ve belâgat konuları ağırlık kazanırken ikinci kısımda ise ayetlerin kast-ı mahsusu üzerine düşünceleri önemli bir yer tutar. Çalışmanın geneli itibariyle sahih inanç bağlamında katkılar sunmaya çalışmıştır.

Atûfînnin Keşşâf haşiyesiyle ilgili başka çalışmalar da yapılmalıdır. Eserin tahkik, tercüme ve tıpkı basım çalışmaları yapılması bunlardan bazıları olabilir. Ayrıca diğer disiplinlerden de istifade ederek dönemin tefsir algısına, toplumun dinsel bilinç düzeyinin tesbitine, toplumsal inanç sorunlarında ve çözümlerinde tefsirin yerine yönelik incelemeler bağlamında ele alınabilir.

\section{Kaynakça / References}

Ahatlı, Erdinç (2011). “Temrîz”, DiA, ss.433-434.

Aslantürk, Ayşe Humeyra (2006). "Necmeddin Nesefî", Di̇A, ss.571-573.

Atûfî, Hayreddin Hızır (t.y.) Hâşiyetü alâ Tefsîri'l-Keşşâf li Mevlânâ 'Atûfí 'alâ Cüzi'n-Nebei ilâ Âhirihî, Şehid Ali Kolleksiyonu no: 263.

Atûfî, Hayreddin Hızır (t.y.) Hâşiyetü 'ale'I-Keşşâf li'l-'Atûfî, Süleymaniye Ktp., Yeni Camii, nr. 144.

Atûfî, Hayreddin Hızır (t.y.) Hâş̧yetü ale'I-Keşşâf bi Hatt-ı Müellifihi li'I-'Atûfî, Süleymaniye, Reisü'l-Küttâb Kolleksiyonu no: 927.

el-Ednevî (1997). Tabakâtül- Müfessirîn, 1.bsk., (tahk. Süleyman b. Salih el-Huzey), Mektebetü'l- Ulûm ve'lHükm es-Saûdiyyi.

el-Askalânî (1998). ỉbn Hacer, el-Metâlibü'I-Âliye bi Zevâid-i Mesânîdi's-Semâniye, Dâru'I-Âsımeti.

el-Bağdâdî, Bâbânzâde İsmâ'îl Paşa (1951). Hediyyetu'I-Ârifîn Esmâ'u'I-Muellifin ve Âsâru'I-Müsannifin, ìstanbul: Mektebetu'I-İslâmiyyeti ve'l-Ca'ferî Tebrizî.

el-Bağdâdî, İsmail b. Muhammed el-Bâbânî (1951). Hediyyetü'I-Arifîn Esmâü'l-Müellifîn ve Âsâru'lMusanifinn, İst: Behiyye Matbaası; Lübnan: Daru'I-Ihyai't-Türâsi'l-islâmî.

el-Beydâvî (1418). Envâru't-Tenzîl ve Esrâru't-Tevîl. (thk. Muhammed Abdurrahman el-Mar'aşlı), Beyrut: Daru'I-Ihyâit-Türâsi'l-Arabiyyi.

el-Bûsayrî, el-Kinâî eş-Şâfiî, Ebu'I-Abbas Şihâbü'd-Din Ahmed (1999). ithâfü'I-Hiyerati'I-Meherati bi Zevâid-i Mesânîdi'I-Aşerati, (thk. Ebû Temîm Yâsir b. İbrâhîm), Riyâd: Dâru'I-Vatan.

el-Mellâh, Ebû Abdurrahman Mahmûd b. Muhammed (2010). el-Ehâdîsu'd-Daîfeti ve'l-Mevdûati elletî Hakeme Aleyhâ Hafız ibn Kesîr fî Tefsîrihî, el-Medînetü'I-Münevveratü: Mektebetü'l-Ulûm ve'I-Huküm,

Erünsal, İsmâil E. (2015). Osmanlılarda Kütüphaneler ve Kütüphanecilik, İstanbul: Timaş Yay.

ez-Zemahşerî, Cârullah (2003). Tefsîru'I-Keşşâf, Lübnan: Dâru'I-Kütübi'I-IImiyye. 
ez-Ziriklî, Hayruddin (1984). el-A'âm Kâmûsu Terâcimi'l-Eşheri'r-Ricâl ve'n-Nisấ' mine'l-'Arab ve'lMusta'rabîn ve'l-Musteşrikin, Beyrût: Dâru'I-'ilmi li'I-Melâyîn.

ibn Ebî Şeybe, Ebubekir (1409). Kitabü'I-Müsannef fi'I-Ahadîs-i ve'I-Âsâr, Riyad: Mektebetü'r-Rüşd.

İbn Mübârek, Abdullah (t.y.). ez-Zühd ve'r-Rekâik li ibni'I-Mübârek, Beyrut: Daru'I-Kütübi'I-IImiyye.

Kara, İsmail (2011). "Unuttuklarını Hatırla! Şerh ve Hâşiye Meselesine Dair Bir Kaç Not", Divan

Disiplinlerarası Çalışmalar Dergisi.

Kara, Osman (2017). “Osmanlı’da Tefsir Hâşiyesi Geleneği: Atûfi Örneği”, AiBÜ ilahiyat Fakültesi Dergisi.

Kâtip Çelebî (Hacı Halife) (1941). Keş̧ü'z-Zünûn, Bağdat: Mektebetü'I-Müsennâ.

Kehhâle, Umar Rıḍâ (t.y.). Mu'cemu'I-Muellifîn Terâcimu Mușannifiyyi'I-Kutubi'l-'Arabiyyeti, Beyrût: Mektebetu'I-Muŝennâ ve Dâru ịhyâi't-Turâsi'I-'Arabi.

Nüveyhiz, Adil (1988). Mu'cemü'I-Müfessirîn, Müessesetü Nüveyhizi's-Sekâfî.

Taşköprîzâde, Ahmed b. Mustafa b. Halîl (t.y.). eş-Şekâiku'n-Nu'mâniyye fi Ulemâi'd-Devleti'l-islâmiyyeti, Beyrut: Daru'I-Kütübi'I-Arabiyye.

Tezcan, Tuğrul (2016). “Hayreddin Hızır El-Atûfî ve Hısnu'I-Âyati'l-I'zâm fî Tefsir-i Evâil-i Sûreti'l-En'âm Risalesi” III. Uluslararası Şeyh Şa'ban-ı Veli Sempozyumu.

\section{Internet Kaynakları / Web Sources}

http://www.tdk.gov.tr/index.php?option=com_tarama\&arama=kelime\&guid=TDK.GTS.5ac253c229ea07.4 8271326

https://ipfs.io/ipns/tr.wikipedia-on-ipfs.org/wiki/Sazl\%C4\%B1ca\%2C_Merzifon.html 